• 研究报告・

\title{
浙江古田山次生与老龄常绿阔叶林群落 特征的比较
}

\author{
张田田 ${ }^{1}$ 王 璇 ${ }^{2}$ 任海保 ${ }^{2}$ 余建平 $^{3}$ 金 毅 ${ }^{1}$ \\ 钱海源 ${ }^{3}$ 宋小友 ${ }^{3}$ 马克平 ${ }^{2}$ 于明坚 ${ }^{*}$ \\ 1 (浙江大学生命科学学院, 杭州 310058) \\ 2 (中国科学院植物研究所植被与环境变化国家重点实验室, 北京 100093) \\ 3 (钱江源国家公园生态资源保护中心, 浙江开化 324300)
}

\begin{abstract}
摘要: 常绿阔叶林为东亚亚热带地区的地带性植被, 对该地区的生物多样性维持和社会发展具有重要的意义。由 于长期人类活动的影响, 目前我国分布的常绿阔叶林绝大部分为次生常绿阔叶林。探究次生与老龄常绿阔叶林群 落特征的差异, 有利于了解人类干扰对亚热带常绿榈叶林的影响, 为其保护和恢复提供依据。本研究在古田山老 龄与次生常绿阔叶林内共设置了 29 个 0.04 ha样地, 比较两者在优势种组成、物种和功能多样性以及生物量等方面 的差异。结果表明: (1)次生林与老龄林优势种组成相似, 二者均以甜槠(Castanopsis eyrei)、木荷(Schima superba) 等典型常绿阔叶林优势种为主, 但这些树种在次生和老龄常绿阔叶林中的优势度次序不同。(2)整体而言, 次生林 的Shannon-Wiener指数和功能离散度高于老龄林; 次生林与老龄林的物种Bray-Curtis指数和功能Sørensen指数均 无显著差别。(3)就垂直层次而言, 次生林与老龄林在Shannon-Wiener指数和Bray-Curtis指数的差异主要体现在乔 木层和灌木层。(4)就群落结构而言, 次生林的植株密度高于老龄林, 但群落水平和个体水平的生物量均显著小于 老龄林。上述结果表明, 人类干扰改变了古田山常绿阔叶林群落的多个重要特征, 不同群落特征的恢复过程并不 同步。因此，对常绿阔叶林生物多样性和生态系统功能的保护和恢复需要从多个角度着手。
\end{abstract}

关键词：老龄林; 次生林; 物种组成; $\alpha$ 多样性; $\beta$ 多样性; 功能性状; 生物量; 植株密度

\section{A comparative study on the community characteristics of secondary and old-growth evergreen broad-leaved forests in Gutianshan, Zhejiang Province}

Tiantian Zhang ${ }^{1}$, Xuan Wang ${ }^{2}$, Haibao Ren², Jianping $\mathrm{Yu}^{3}$, Yi Jin ${ }^{1}$, Haiyuan Qian ${ }^{3}$, Xiaoyou Song ${ }^{3}$, Keping $\mathrm{Ma}^{2}$, Mingjian $\mathrm{Yu}^{1 *}$

1 College of Life Sciences, Zhejiang University, Hangzhou 310058

2 State Key Laboratory of Vegetation and Environmental Change, Institute of Botany, Chinese Academy of Sciences, Beijing 100093

3 Center of Ecology and Resources, Qianjiangyuan National Park, Kaihua, Zhejiang 324300

\begin{abstract}
Evergreen broad-leaved forests (EBLFs), which are the primary zonal vegetation of subtropical East Asia, shelter high biodiversity and contribute significantly to human welfare. Today, most EBLFs are secondary growth due to long-term human activity. The few remaining old-growth EBLFs are small, scattered patches. Understanding how secondary and old-growth EBLFs differ in their community characteristics would provide guidance for their conservation and restoration. Here, we compare the dominant species composition, species and functional diversity, and aboveground biomass between old-growth (fifteen $20 \mathrm{~m} \times$ $20 \mathrm{~m}$ plots) and secondary (fourteen $20 \mathrm{~m} \times 20 \mathrm{~m}$ plots) EBLFs in Gutianshan National Nature Reserve (GNNR). We found that: (1) Both old-growth and secondary EBLFs were dominated by the same set of
\end{abstract}


evergreen broad-leaved species, such as Castanopsis eyrei and Schima superba, but the species dominance order was inconsistent in the two forest types. (2) Secondary EBLFs had a higher Shannon-Wiener index value and greater functional dispersion than old-growth EBLFs, but neither the Bray-Curtis dissimilarity index values nor the functional Sørensen index values differed greatly between secondary and old-growth EBLFs. (3) When considering three vertical forest layers separately, the differences in the Shannon-Wiener and Bray-Curtis indices between secondary and old-growth EBLFs were mainly reflected in the tree and shrub layers. (4) Looking at the community structure overall, the stem density was greater in secondary EBLFs than old-growth EBLFs. Additionally, the community level and the individual level biomass were both lower in secondary EBLFs than old-growth EBLFs. These findings suggest that human disturbance has changed multiple characteristics of the EBLFs in GNNR, and their recovery process has been asymmetrical. Accordingly, any conservation plans to restore the biodiversity and ecosystem functioning in EBLFs should adopt a multi-faceted strategy.

Key words: old-growth forest; secondary forest; species composition; $\alpha$ diversity; $\beta$ diversity; functional trait; biomass; stem density

亚热带常绿阔叶林是世界主要森林植被类型 之一, 主要分布在中国, 以中亚热带的常绿阔叶林 最为典型(吴征镒，1980; 王希华，2006; 宋永昌， 2013; Jin et al, 2018)。亚热带常绿阔叶林区域约占 中国国土面积的 $1 / 4$, 其结构复杂, 生物多样性丰富, 生态系统服务功能强, 对中国社会经济的可持续发 展及生态安全有着重要作用。由于长期的人类干扰, 中国亚热带常绿阔叶林绝大部分退化为次生林或 被改造为人工林, 老龄林几乎丧失殆尽 (吴征镒, 1980; 宋永昌等, 2005; Wang et al, 2007; Shang et al, 2014)。比较亚热带次生和老龄常绿阔叶林群落特征 的差异, 对次生常绿阔叶林植被恢复和生物多样性 保护有重要意义。

人类干扰可影响森林生物多样性和群落结构, 森林在受到干扰后的恢复过程受到关注(Bruelheide et al, 2011; Feng et al, 2014; Liu et al, 2016)。一方面, 在干扰后的演替过程中, 森林物种组成和多样性 (Aiba et al, 2001)均可发生巨大变化, 进而引起群落 功能多样性(Biswas \& Mallik, 2010; Hu et al, 2014) 和生态系统功能(Huang et al, 2018)的改变; 另一方 面, 干扰后, 森林群落的生物量等特征会随演替进 展发生变化(Pregitzer \& Euskirchen, 2004; Ali et al, 2016)。已有研究表明, 次生林的恢复过程受到干扰 历史、地形等环境因素及生物因素的共同影响 (Chazdon et al, 2007; Bruelheide et al, 2011), 不同群 落常表现出不同的恢复速度, 并且对于不同功能性 状的物种, 其组成和多样性的恢复速度也存在差异 (Aiba et al, 2001; Martin et al, 2004; 冯广等, 2016)。 处于不同演替阶段的次生林之间在物种组成、群落
结构等诸多方面存在差异, 且因地区和次生林的恢 复时间而异(包维楷和刘照光, 2002; 史景宁等, 2015)。但迄今关于次生与老龄常绿阔叶林群落的比 较研究极少, 以往在古田山进行的干扰历史和干扰 强度对森林群落及其动态的影响研究均未涉及这 一方面(Feng et al, 2014; 徐远杰等, 2014)。

古田山国家级自然保护区地处我国中亚热带 东部, 其地带性植被老龄常绿阔叶林在核心区内低 海拔地区广泛分布, 周围的缓冲区和实验区分布有 更大面积的次生常绿润叶林(于明坚等, 2001, 2019), 为比较研究亚热带次生和老龄常绿阔叶林群落特 征提供了良好的材料。本文拟通过比较古田山次生 和老龄常绿阔叶林群落的优势种组成、物种和功能 多样性、植株密度和生物量的差异, 探究两者物种 组成和群落结构的差异, 为亚热带常绿阔叶林的生 物多样性保护和恢复提供依据。

\section{材料与方法}

\section{1 研究区概况}

古田山国家级自然保护区 $\left(29^{\circ} 10^{\prime}-29^{\circ} 17^{\prime} \mathrm{N}\right.$, $\left.118^{\circ} 03^{\prime}-118^{\circ} 11^{\prime} \mathrm{E}\right)$ 地处黄山、怀玉、白际山脉交汇 处, 面积8,107 ha。该区属中亚热带湿润季风气候, 年均温 $15.3^{\circ} \mathrm{C}$, 最热月均温 $28.9^{\circ} \mathrm{C}$, 最冷月均温 $4.1^{\circ} \mathrm{C}$, 年均降水量 $1,963.7 \mathrm{~mm}$, 年均降雨天数约 $140 \mathrm{~d}$, 无 霜期约 $250 \mathrm{~d}$ (于明坚等, 2001)。土壤类型有红壤、 红黄壤、黄红壤及高山草甸土, 由于地形复杂, 形 成了多种小气候和植被类型(楼炉焕和金水虎, 2000; 胡正华等, 2003), 分布有中亚热带地区少见的大面 积低海拔老龄常绿阔叶林(于明坚等, 2001)。通过查 
阅资料和实地走访调查, 我们将从未受到明显人类 干扰、保存完好的森林群落认定为老龄林, 将受到 砍伐等人类干扰后经次生演替自然恢复的森林群 落认定为次生林。次生林主要为1958年建立伐木场 后，因用材需求皆伐后恢复的天然次生林。1975年 古田山成立省级自然保护区后，人为砍伐现象得到 控制(开化林业志编写组, 1988), 2001年成立国家级 自然保护区并扩区后完全禁止。确定了老龄林大概 分布范围后, 经估算发现保护区内老龄常绿阔叶林 约占常绿阔叶林总面积的 $10 \%$, 面积达到 549 ha。

\section{2 样地设置及调查方法}

在保护区内选择有代表性的地点, 共设置29个 $20 \mathrm{~m} \times 20 \mathrm{~m}$ 样地, 其中老龄常绿润叶林 (以下简称 老龄林)样地 15 个; 次生常绿阔叶林(以下简称次生 林)样地 14 个, 样地间隔大于 $140 \mathrm{~m}$ 。次生林位于保 护区的实验区和缓冲区, 距离村庄、道路等较近; 老龄林主要位于核心区, 人迹罕至, 其中常保留有 胸径较大、树高较高的植株(比如马尾松 (Pinus massoniana)、甜槠(Castanopsis eyrei)和木荷(Schima superba))。为了解次生林恢复时间长度, 利用 Bruelheide等(2011)的公式, 通过样地内胸径排名前 五的乔木层个体的平均年龄推算出次生林林龄。每 个样地被划分为 16 个 $5 \mathrm{~m} \times 5 \mathrm{~m}$ 小样方, 以 $1 \mathrm{~cm}$ 为起 测胸径(离地1.3 $\mathrm{m}$ 的主干直径), 对样地内木本植物 进行每木调查, 测定坐标、胸径, 并鉴定物种, 部分 样地还测定了植株高度。在每个样地中央位置记录 经纬度和地形因子。地形因子包括海拔、坡度和坡 向。此外, 基于人类干扰程度的不同, 将几乎未受 人类干扰的样地划入老龄林, 干扰强(如皆伐)的样 地划分为次生林。

\section{3 功能性状}

群落内的生境因子会随演替过程发生变化, 导 致物种在光合效率、植株高度和传播方式等方面均 发生显著改变(李庆康和马克平, 2002; 宋光满等, 2018)。因此, 我们选择了叶生活型、生长型和传播 方式3个物种水平上的功能性状(李庆康和马克平, 2002; R Ehounková\& Prach, 2010)。其中，叶生活型 包括常绿阔叶、落叶阔叶和针叶; 生长型包括灌木 和乔木; 传播方式包括动物传播(zoochory)、风力传 播(anemochory)和自身传播(autochory)。

\section{4 群落结构}

部分样地缺少树高数据, 我们利用Lin等(2012)
提供的方程通过胸径估算树高，未列出的其他物种 利用近缘种公式来计算，若无近缘种，利用“其他 树种”方程来估算。参考冀艳利 ${ }^{1}$ 对古田山常绿阔叶 林垂直层次的划分标准，根据树高将群落划分为三 个层次：灌木层 $(<5 \mathrm{~m})$ 、亚乔木层 $[5 \mathrm{~m}, 15 \mathrm{~m})$ 和乔 木层 $(\geq 15 \mathrm{~m})$ 。

计算每个样地的植株密度(株/ha)。利用主要树 种的生物量方程(附录1)估算每株植物的地上部分 生物量, 未列出的物种采用其近缘种的生物量方程 估算; 无近缘种的物种利用“其他树种”方程估算， 这类物种约占总个体数的 $10 \%$ 。

\section{5 统计与分析方法}

\subsection{1 优势种组成}

采用重要值(importance value, IV)衡量物种的 优势度(宋永昌, 2016)。以样地群落数据为基础, 分 别计算老龄林和次生林的物种重要值。公式为 $I V=$ $(D r+P r+F r) / 3$ 。其中, $D r$ 为相对多度 $($ 某个种的株 数/全部种的总株数), $\operatorname{Pr}$ 为相对显著度(某个种的胸 高断面积/全部种的胸高断面积), $\mathrm{Fr}$ 为相对频度(某 个种在 $5 \mathrm{~m} \times 5 \mathrm{~m}$ 小样方的频度/全部种的总频度)。

\subsection{2 物种和功能多样性指标}

以Shannon-Wiener指数 $\left(H^{\prime}\right)\left(H^{\prime}=-\Sigma p_{\mathrm{i}} \ln p_{\mathrm{i}}, p_{\mathrm{i}}\right.$ 为 物种相对多度) 衡量物种 $\alpha$ 多样性。以Bray-Curtis指 数衡量物种 $\beta$ 多样性(物种组成差异)。对老龄林和次 生林进行稀疏化(rarefaction)分析，稀疏曲线能较为 客观地反映个体数与物种丰富度的关系(黄冰, 2012)。

用功能离散度(functional dispersion, Fdis)衡量 群落的功能 $\alpha$ 多样性(Lalibert \& Legendre, 2010)。功 能离散度反映了群落内功能性状的异质性, 是指每 个物种离所有物种功能性状多维空间质心的平均 距离, 并经物种相对多度加权, 不受物种丰富度的 影响(Laliberté \& Legendre, 2010)。用Sørensen指数 衡量功能 $\beta$ 多样性(功能组成差异)(Baselga, 2012), 它通过逐对比较样地间的功能性状相异性，反映两 个群落之间的总体 $\beta$ 多样性。物种间功能性状距离 采用Gower距离计算(Gower, 1971)。

\subsection{3 统计方法}

采用Wilocoxon秩和检验 (Wilcoxon rank-sum test) 比较次生林与老龄林在Shannon-Wiener指数和

(1) 冀艳利 (2016) 古田山 24 ha样地木本植物物种多样性及优势种群更 新动态研究. 硕士学位论文, 浙江师范大学, 浙江金华. 
功能离散度两个方面的差异。进一步, 分别在乔木 层、亚乔木层和灌木层比较次生林与老龄林间 Shannon-Wiener指数的差异。采用卡方检验分析次 生林和老龄林群落在各个功能群所占相对丰富度 及相对多度的差异。利用线性回归模型控制地形因 子作用, 了解人类干扰对 Shannon-Wiener指数和功 能离散度的影响。地形因子中, 坡向为环状变量, 被分解为南北向(坡向的余弦值)和东西向(坡向的 正弦值)分量。然后, 选出AICc值最小的模型作为最 优模型(附录2,3)。采用Wilocoxon秩和检验评估老 龄林与次生林内部及二者之间物种Bray-Curtis指数 和功能Sørensen指数的差异(Borcard et al, 2011)。进 一步利用偏Mantel检验的多元回归方法, 在控制地 形和地理距离影响的基础上, 了解人类干扰对物种 Bray-Curtis指数和功能Sørensen指数的影响。

通过Wilcoxon秩和检验比较次生林和老龄林间 植株密度的差异, 并分别比较次生林和老龄林在群 落和个体水平的生物量差异。用Levene检验分析次 生林和老龄林内个体水平生物量变异程度的差异。 通过模型选择和线性回归模型，在考虑地形因素影 响的同时, 了解人类干扰对森林群落水平上生物量 和植株密度的影响。进一步, 用卡方检验分析次生林 与老龄林生物量在三种功能性状组成上的差异。

为进一步了解林龄对群落结构特征的影响, 利 用一元线性回归模型, 探究次生常绿阔叶林 Shannon-Wiener指数、功能离散度、植株密度和地 上部分生物量与林龄的线性关系。

所有数据分析均通过R 3.2.4软件(R Core Team,
2016)进行。其中稀疏曲线和nMDS分析采用vegan 软件包(Oksanen et al, 2016), 地理距离计算采用 fossil软件包(Matthew，2012)，功能离散度计算采用 FD软件包(Laliberté et al, 2014), 偏mantel检验采用 phytools 软件包(Revell, 2012), 线性回归模型的模 型选择使用MuMIn软件包(Bartoń, 2017)。

\section{结果}

\section{1 物种组成}

29 个 0.04 ha样地共调查到木本植物 50 科 95 属 164 种，其中常绿阔叶植物85种，落叶阔叶植物 77 种，针叶植物 2 种。15个老龄林样地含木本植物 42 科77属123种，其中常绿阔叶植物 71种，落叶阔叶 植物 50 种, 针叶植物 2 种, 0.04 ha样地平均物种数为 $30.9 \pm 8.5 ; 14$ 个次生林样地含 40 科78属 133 种, 0.04 ha样地平均物种数为 $38.8 \pm 8.6$, 其中常绿榈叶植物 72 种, 落叶阔叶植物 59 种, 针叶植物 2 种, 次生林样 地内物种数显著高于老龄林 $(P<0.05$, Wilcoxon秩 和检验)。

次生林和老龄林均具有明显优势种, 且物种组 成较为相似(表1)。二者的差异主要体现在优势种的 次序, 老龄林重要值前三位的乔木为甜楮、木荷和 马尾松, 灌木为马银花 (Rhododendron ovatum)、格药 柃(Eurya muricata)和鹿角杜鹃(Rhododendron latoucheae); 次生林重要值前三位的乔木为木荷、 甜槠和青冈(Cyclobalanopsis glauca), 灌木为聯木 (Loropetalum chinense)、格药柃和鹿角杜鹃。值得 注意的是, 杉木(Cunninghamia lanceolata)在次生林

表1 古田山国家级自然保护区老龄和次生常绿阔叶林重要值排名前十的木本植物

Table 1 Importance value (IV) of the top 10 dominant species in old-growth and secondary evergreen broad-leaved forests in Gutianshan National Nature Reserve

\begin{tabular}{lll||lll}
\hline 排名 Rank & 老龄林 Old-growth forest & 重要值 $I V$ & 排名 Rank & 次生林 Secondary forest & 重要值 $I V$ \\
\hline 1 & 甜楮 Castanopsis eyrei & 17.22 & 1 & 木荷 Schima superba & 16.86 \\
2 & 木荷 Schima superba & 9.09 & 2 & 甜楮 Castanopsis eyrei & 11.34 \\
3 & 马银花 Rhododendron ovatum & 5.00 & 3 & 格药柃 Eurya muricata & 4.25 \\
4 & 格药柃 Eurya muricata & 3.63 & 4 & 檵木 Loropetalum chinense & 3.80 \\
5 & 马尾松 Pinus massoniana & 3.09 & 5 & 青冈 Cyclobalanopsis glauca & 3.42 \\
6 & 虎皮楠 Daphniphyllum oldhami & 3.07 & 6 & 石栎 Lithocarpus glaber & 3.26 \\
7 & 红楠 Machilus thunbergii & 2.54 & 7 & 马尾松 Pinus massoniana & 2.46 \\
8 & 青冈 Cyclobalanopsis glauca & 2.45 & 8 & 鹿角杜鹃 Rhododendron latoucheae & 2.23 \\
9 & 毛花连莣茶 Camellia trichoclada & 2.41 & 9 & 杉木 Cunninghamia lanceolata & 2.22 \\
10 & 鹿角杜鹃 Rhododendron latoucheae & 2.12 & 10 & 马银花 Rhododendron ovatum & 2.21 \\
\hline
\end{tabular}


中的重要值排在前十位。

\section{2 物种多样性和功能多样性}

Wilcoxon秩和检验显示, 整体上次生林的 Shannon-Wiener指数显著高于老龄林(图1A)。就垂 直层次而言, 次生林灌木层的Shannon-Wiener指数 显著高于老龄林，而乔木层则显著低于老龄林，但 亚乔木层差异不显著(图2)。考虑地形影响后所选出 的最优线性回归模型结果显示，人类干扰和坡向对 Shannon-Wiener指数有显著影响 (表2, 附录2), 但 次生林林龄与Shannon-Wiener指数并没有显著的线 性相关关系(图3)。稀疏曲线显示取样个体数较少时,
次生林内单位个体包含的物种数大于老龄林, 次生 林物种丰富度随个体数的增加而快速上升，比老龄 林更早达到平缓(图4)。另一方面，次生林的功能离 散度也显著高于老龄林(图1B); 但针对功能离散度 的最优线性回归模型显示人类干扰的影响并不显 著(表2，附录3)。次生林所含常绿阔叶植物的相对丰 富度和相对多度均低于老龄林，落叶阔叶植物的相 对丰富度高于老龄林，而生长型和传播方式的不同 功能群在次生林和老龄林所占的相对丰富度和相对 多度均没有显著差异(附录4)。

Wilcoxon秩和检验发现次生林与老龄林的
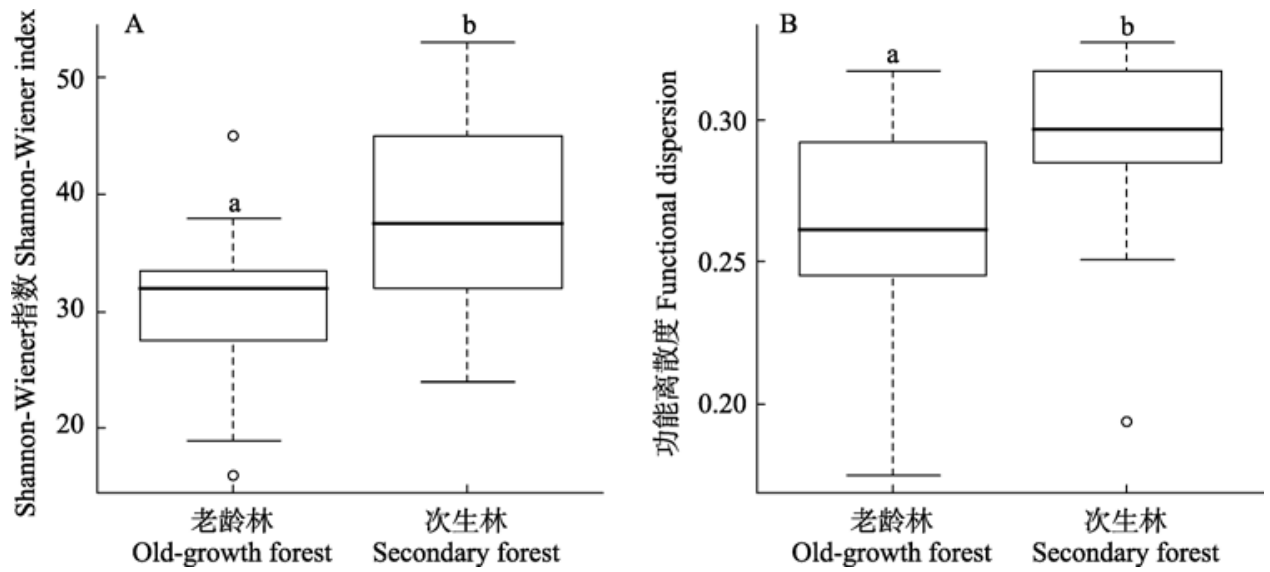

图1 古田山国家级自然保护区老龄和次生常绿阔叶林Shannon-Wiener指数(A)和功能离散度(B)的比较。若两个箱线图上方 的字母不同, 则表明存在显著性差异 $\left(P_{\mathrm{adj}}<\mathbf{0 . 0 5}\right.$, Wilcoxon秩和检验, $P$ 值通过Holm方法校正)。

Fig. 1 Comparisons of Shannon-Wiener index and functional dispersion between old-growth and secondary evergreen broad-leaved forests in Gutianshan National Nature Reserve. Different lower-case letters above the boxes indicate significant pairwise difference $\left(P_{\text {adj }}<0.05\right.$, Wilcoxon rank-sum test, $P$ value was adjusted using the Holm method).
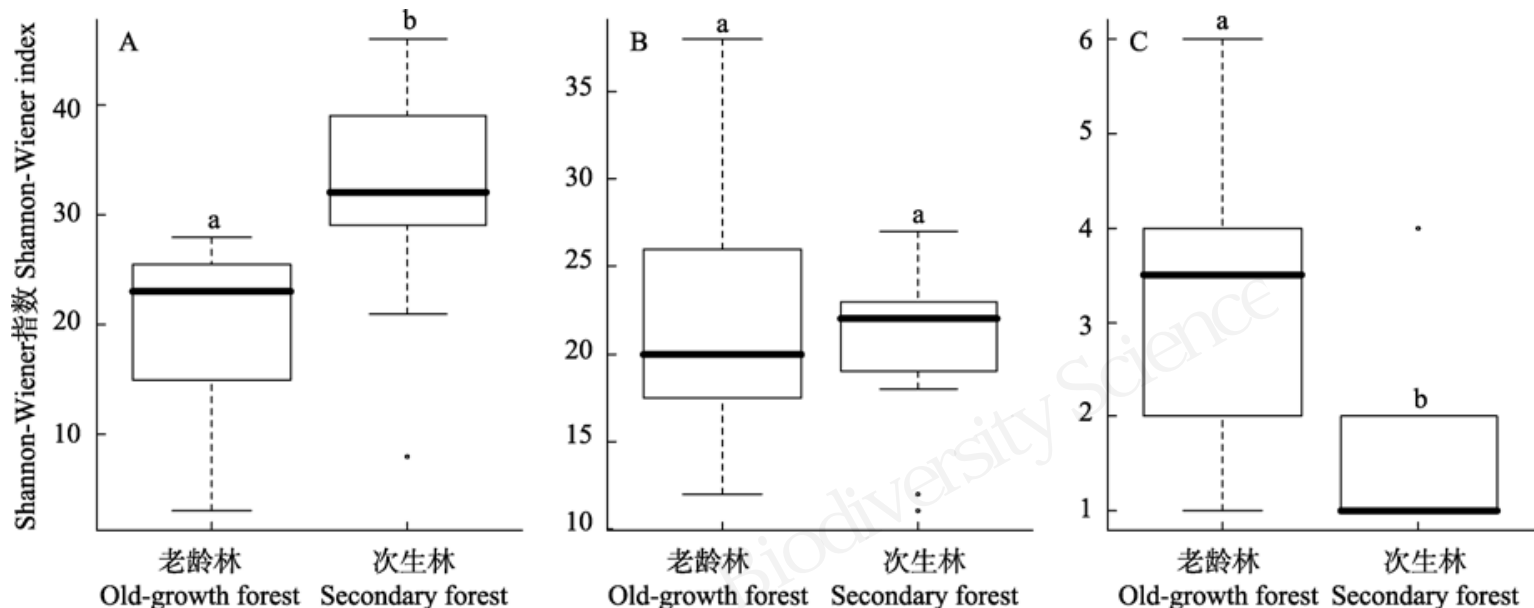

图2＼cjkstart古田山国家级自然保护区老龄和次生常绿阔叶林灌木层(A)、亚乔木层(B)和乔木层(C)的Shannon-Wiener指数比较。若 两个箱线图上方的字母不同, 则表明存在显著性差异 $\left(P_{\text {adj }}<0.05\right.$, Wilcoxon秩和检验, $P$ 值通过Holm方法校正)。

Fig. 2 Comparisons of Shannon-Wiener index of shrub layer (A), sub-tree layer (B) and tree layer (C) between old-growth and secondary evergreen broad-leaved forests in Gutianshan National Nature Reserve. Different lower-case letters above the boxes indicate significant pairwise difference $\left(P_{\text {adj }}<0.05\right.$, Wilcoxon rank-sum test, $P$ value was adjusted using the Holm method). 
表2 古田山国家级自然保护区常绿阔叶林Shannon-Wiener指数和功能离散度与环境因子的关系。*, $\boldsymbol{P}<0.05 ; * *, \boldsymbol{P}<\mathbf{0 . 0 1}$; ***, $\boldsymbol{P}<\mathbf{0 . 0 0 1}$ 。

Table 2 Relationship between environmental factors and Shannon-Wiener index and functional dispersion of evergreen broad-leaved forests in Gutianshan National Nature Reserve. *, $P<0.05$; **, $P<0.01$; ***, $P<0.001$.

\begin{tabular}{lll}
\hline & Shannon-Wiener指数 Shannon-Wiener index & 功能离散度 Functional dispersion \\
\hline 截距 Intercept & $19.933^{* * *}$ & $0.1944^{* * *}$ \\
人类干扰 Human disturbance & $10.271^{* * *}$ & 0.0259
\end{tabular}

$\sin$ (坡向) $\sin$ (Aspect)

$\cos$ (坡向) $\cos$ (Aspect) $\quad-4.658^{*}$

海拔 Elevation

0.0001

坡度 Slope
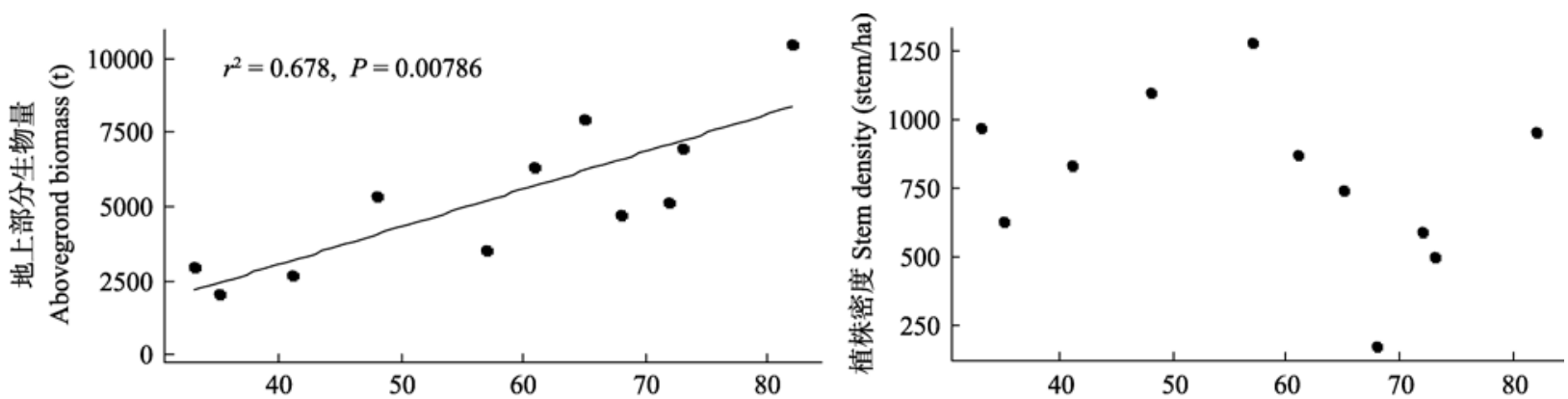

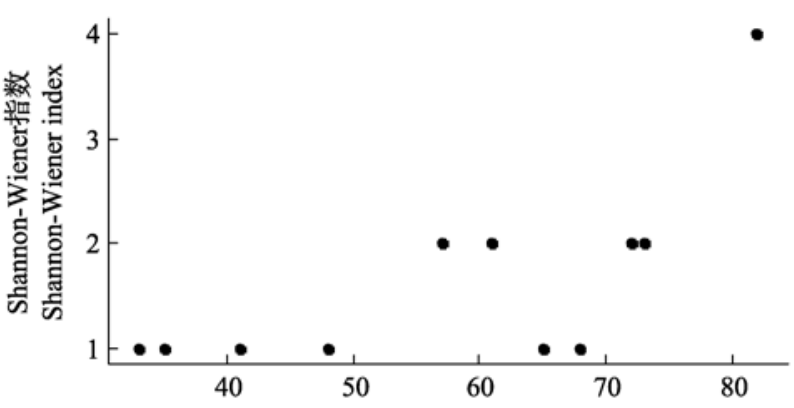

胸径前五的个体平均年龄

Average age of the top five largest trees (yr)

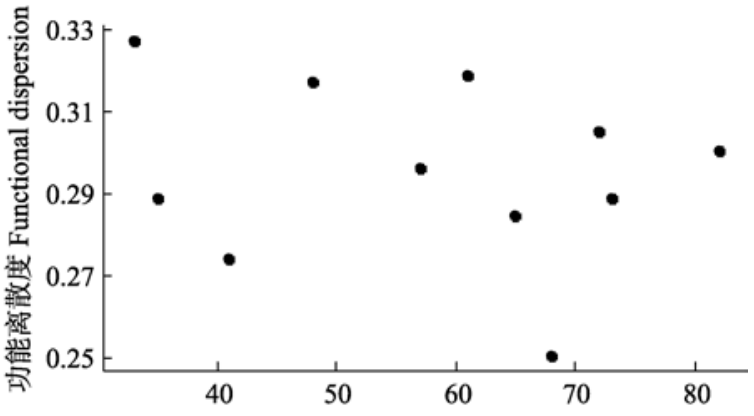

胸径前五的个体平均年龄

Average age of the top five largest trees (yr)

图3 古田山国家级自然保护区次生常绿阔叶林群落特征与林龄的线性回归模型结果

Fig. 3 Linear regression model results of age effects on community structure of secondary evergreen broad-leaved forests in Gutianshan National Nature Reserve

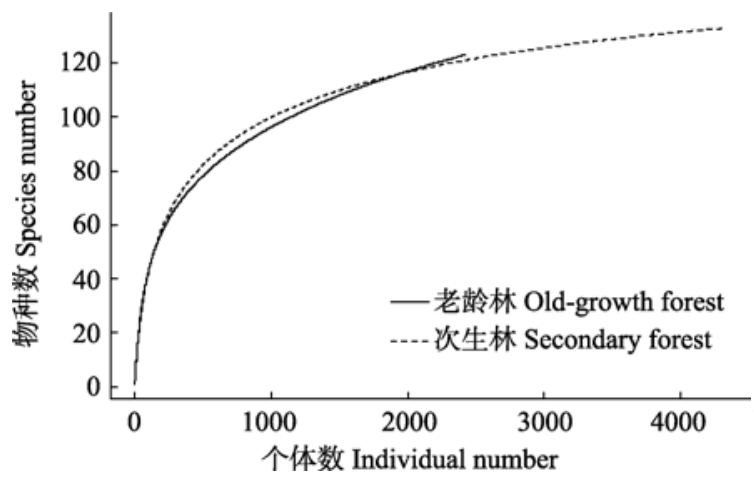

图4 古田山国家级自然保护区老龄林和次生林的物种稀疏 曲线

Fig. 4 Species rarefaction curves of old-growth forest and secondary forest in Gutianshan National Nature Reserve
Bray-Curtis 指数略有差异 (图 5A)。次生林间的 Bray-Curtis指数显著低于次生林与老龄林间的 Bray-Curtis指数，而老龄林间和次生林与老龄林间 没有显著差异。针对功能 $\beta$ 多样性的Wilcoxon秩和检 验显示, 次生林与老龄林间的功能Sørensen指数显 著小于老龄林, 但次生林与老龄林内没有显著差异 (图5B)。进一步, 用偏Mantel检验的多元回归方法控 制地形和地理距离的影响后, 发现人类干扰对物种 Bray-Curtis指数和功能Sørensen指数的影响均不显 著(附录5)。就垂直层次而言, 次生林内灌木层的 Bray-Curtis指数显著低于老龄林, 乔木层则显著高 于老龄林，但亚乔木层没有显著差异(图6)。 


\section{3 群落结构}

次生林的植株密度 $(773.9 \pm 277.9$ 株/ha) 显著 高于老龄林(404 \pm 163.9 株/ha) $(P<0.001$, Wilcoxon秩和检验)。线性回归结果显示, 控制地形影响 后，人类干扰对植株密度有显著影响(附录6，表3)。 但次生林的林龄与植株密度没有显著的线性相关 性(图3)。

次生林 0.04 ha样地的地上部分生物量 $(5.25 \pm$
$2.31 \mathrm{t})$ 显著低于老龄林 $(8.09 \pm 3.04 \mathrm{t})(P<0.01$, Wilcoxon秩和检验)。次生林地上部分生物量随林龄 的增加有显著增加的趋势(图3)。控制地形影响后, 人类干扰对地上生物量有显著影响(附录7，表3)。次 生林和老龄林在叶生活型、生长型和传播方式等不 同功能群的生物量所占比例上均无显著差别(附录 8)。另一方面, 次生林植株个体的生物量显著小于 老龄林 $(P<0.001$, Wilcoxon秩和检验 $)$, 但次生林个
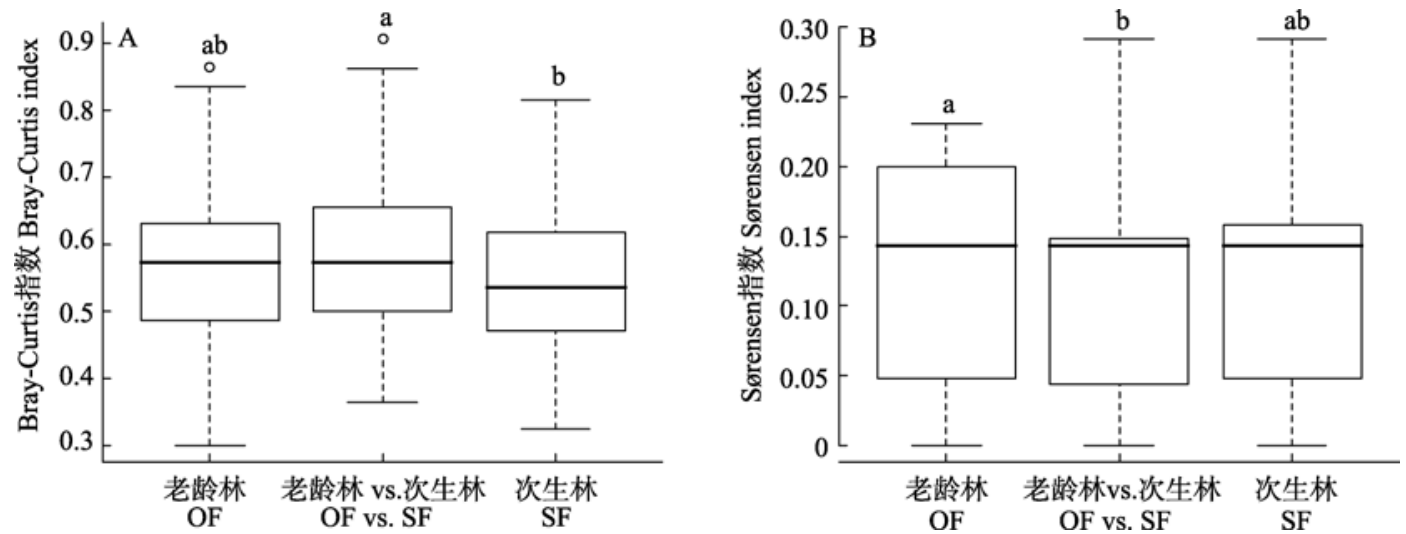

图5 古田山国家级自然保护区老龄和次生常绿阔叶林间物种Bray-Curtis指数(A)和功能Sørensen指数(B)比较。若两个箱线 图上方的字母不同, 则表明存在显著性差异 $\left(P_{\text {adj }}<0.05\right.$, Wilcoxon秩和检验, $P$ 值通过Holm方法校正)。

Fig. 5 Comparisons of species Bray-Curtis index (A) and functional Sørensen index (B) between old-growth and secondary evergreen broad-leaved forests in Gutianshan National Nature Reserve. Different lower-case letters above the boxes indicate significant pairwise difference ( $P_{\text {adj }}<0.05$, Wilcoxon rank-sum test, $P$ value was adjusted using the Holm method). OF, Old-growth Forest; SF, Secondary Forest.
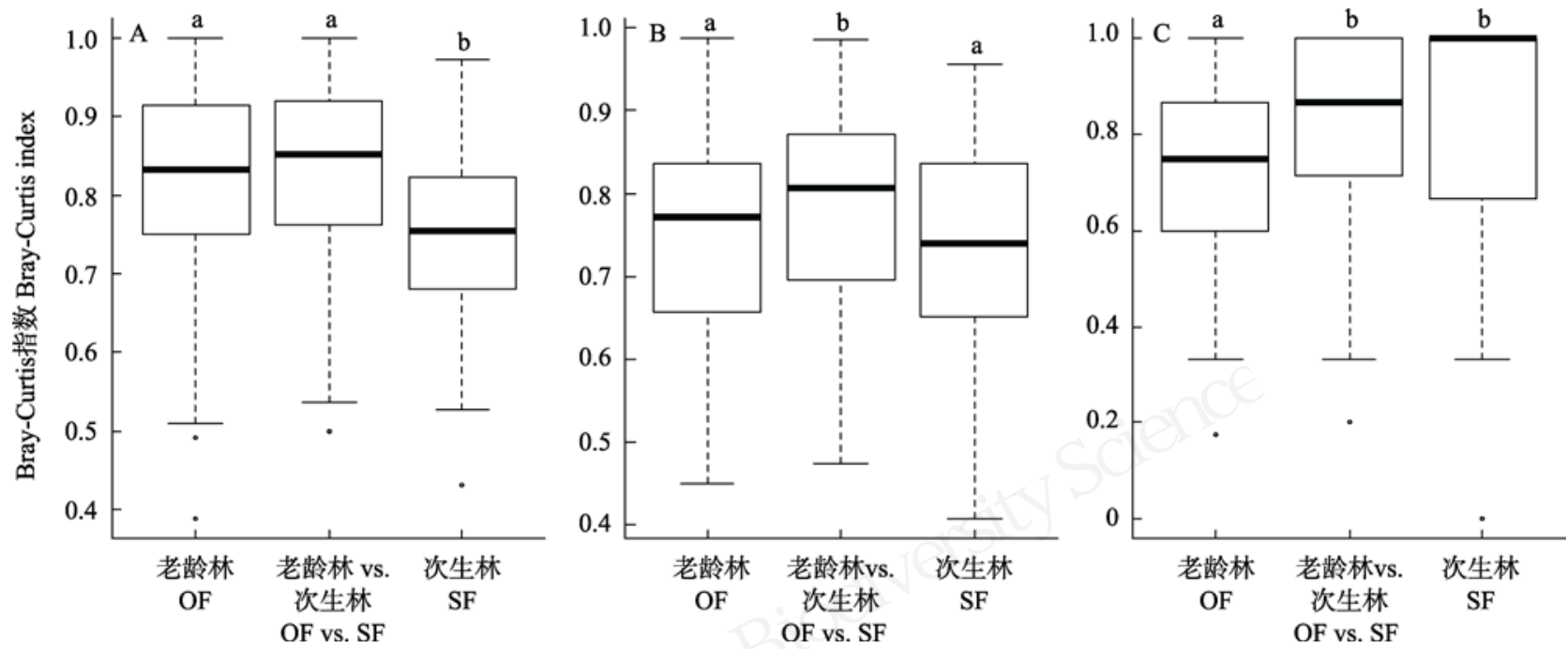

图6 古田山国家级自然保护区老龄和次生常绿阔叶林灌木层 $(\mathrm{A})$ 、亚乔木层 $(\mathrm{B})$ 和乔木层 $(\mathrm{C})$ 的物种Bray-Curtis指数比较。若 两个箱线图上方的字母不同, 则表明存在显著性差异 $\left(P_{\text {adj }}<0.05\right.$, Wilcoxon秩和检验, $P$ 值通过Holm方法校正)。

Fig. 6 Comparisons of species Bray-Curtis index of shrub layer (A), sub-tree layer (B) and tree layer (C) between old-growth and secondary evergreen broad-leaved forests in Gutianshan National Nature Reserve. Different lower-case letters above the boxes indicate significant pairwise difference ( $P_{\text {adj }}<0.05$, Wilcoxon rank-sum test, $P$ value was adjusted using the Holm method). 
表3 环境因子对样地植株密度和地上部分生物量影响的线 性回归结果。*, $\boldsymbol{P}<\mathbf{0 . 0 5}$; **, $\boldsymbol{P}<\mathbf{0 . 0 1}$; ***, $\boldsymbol{P}<\mathbf{0 . 0 0 1}$ 。

Table 3 Linear regression model of environmental factors effects on aboveground biomass of each plot. *, $P<0.05$; **, $P<0.01$; ***, $P<0.001$.

\begin{tabular}{lll}
\hline & $\begin{array}{l}\text { 植株密度 } \\
\text { Stem density }\end{array}$ & $\begin{array}{l}\text { 地上部分生物量 } \\
\text { Aboveground biomass }\end{array}$ \\
\hline 截距 Intercept & $-1.4915^{* *}$ & $7231.301^{*}$ \\
人类干扰 & $1.0059^{* * *}$ & $-2881.881^{*}$ \\
Human disturbance & & \\
海拔 Elevation & & 6.135 \\
$\sin$ (坡向) $\sin$ (Aspect) & & \\
$\cos$ (坡向) $\cos$ (Aspect) & & \\
坡度 Slope & $-0.4319^{* *}$ & \\
\hline
\end{tabular}

体水平生物量的变异程度与老龄林无显著差异。

\section{3 讨论}

以往很多研究探讨了人类干扰对常绿阔叶林 演替过程中物种多样性(例如, Aiba et al, 2001; Bruelheide et al, 2011; 徐远杰等, 2014)或谱系多样 性(例如, 宋凯等, 2011; Feng et al, 2014)的影响, 但 仍缺乏对同地区人类干扰对常绿阔叶林群落特征 影响的综合研究(Ding et al, 2012)。本文综合比较了 古田山次生和老龄常绿阔叶林的群落特征, 发现人 类干扰对于常绿阔叶林产生的影响是多元的。

\section{1 物种组成}

次生林与老龄林的主要优势种虽然组成相似, 但各优势种重要值存在一些差异。例如, 木荷和甜 槠虽然都是古田山常绿阔叶林的主要优势种(胡正 华等, 2003), 但甜槠在老龄林中的重要值为木荷的 近2倍, 而在次生林中则低于木荷。这可能是由于甜 櫧耐阴性较强, 在成熟林中更新能力强于木荷, 常 在老龄林中占优势(徐学红等, 2005); 而木荷习性 偏阳性且生长速度快, 在常绿阔叶林恢复过程中常 作为先锋树种(宋永昌, 2013), 因此在次生林内的重 要值更大。优势种组成的相似性说明次生林有向老 龄林演替的潜力, 而其差异性则可能更多地指明了 次生林演替的方向, 长期的群落监测有助于证实这 个猜测。杉木是亚热带地区很好的用材树种, 在古 田山保护区成立前, 当地村民大面积营造杉木人工 林, 保护区建立后人工经营逐渐消失, 有一部分演 替为常绿榈叶林, 但部分杉木个体尚存, 故在古田 山的次生常绿阔叶林中尚有一定优势度(钱海源等,
2018; 于明坚等，2019)。虎皮楠(Daphniphyllum oldhami)和红楠(Machilus thunbergii)也属于耐阴种, 它们在老龄林中的重要值分别占第六和第七位, 也 显示了老龄林与次生林不同的干扰历史。

\section{2 物种多样性和功能多样性}

次生林的Shannon-Wiener指数高于老龄林, 这 与Aiba等(2001)发现日本南部常绿阔叶次生林物种 $\alpha$ 多样性大于老龄林吻合, 也与Wang等(2007)、农友 等(2018)发现常绿阔叶林物种丰富度在演替中期达 到峰值后下降的结果一致。垂直层次上, 次生林与 老龄林的差异主要体现在灌木层和乔木层, 在亚乔 木层则差异不显著。次生林灌木层的Shannon-Wiener 指数较高, 而乔木层显著低于老龄林, 表明亚热带 常绿阔叶林在演替后期会丢失一些灌木物种，比如 本研究中满山红(Rhododendron mariesii)、白背麸杨 (Rhus hypoleuca) 等植物在次生林中存在, 但在老龄 林中未见; 而一些乔木层的演替后期优势种, 如钩 栲(Castanopsis tibetana)、米槠(Castanopsis carlesii) 等物种只出现在老龄林，而未见于次生林。进一步， 次生林的功能离散度显著高于老龄林, 反映了在演 替后期常绿阔叶林中具有某些功能性状特征的物 种可能会减少。物种稀疏曲线表明，老龄林和次生 林均受到生境异质性的较大影响(Stein et al, 2014)。 次生林与老龄林物种丰富度的差异与取样尺度有 关, 大面积的老龄林可能比次生林蕴含着更高的物 种丰富度，体现了森林群落物种多样性的空间异质 性(芦伟等, 2018)。因此本研究中次生林 $\alpha$ 多样性显 著高于老龄林可能是取样面积(0.04 ha)较小所致。

另一方面, 物种Bray-Curtis指数的比较结果显 示次生林与老龄林间的物种组成差异显著高于次 生林内。在不同垂直层次, 次生林与老龄林的物种 Bray-Curtis指数也表现出显著差异。老龄林间的灌 木层物种组成差异较大, 表明在常绿阔叶林演替进 程的后期, 异质性生境条件对常绿阔叶林群落灌木 层的物种组成有较大影响; 同时, 次生林间乔木层 的物种Bray-Curtis指数显著高于老龄林, 说明随着 林龄增长，次生林间乔木层物种组成差异趋于减小 (Ding et al, 2012; Purschke et al, 2013)。但控制地形 和地理距离的影响后, 人类干扰对物种Bray-Curtis 指数和功能Sørensen指数的影响均不显著, 说明次 生林与老龄林物种和功能 $\beta$ 多样性的差异主要受到 环境而非干扰历史的影响。 


\section{3 群落结构}

生物量是重要的生态系统功能(Cardinale et al, 2011), 次生林在群落水平和个体水平的生物量均 显著低于老龄林, 说明次生林的生态系统功能低于 老龄林。次生林比老龄林具有更高的植株密度, 表 明老龄林的生物量更多来源于大植株个体的贡献。 另一方面, 随着林龄的增加, 次生林地上部分生物 量呈增长趋势, 表明人类干扰对地上部分生物量有 显著影响。本研究结果验证了Ali等(2016)认为林龄 是中国东部亚热带次生林地上部分生物量的主要 影响因素的观点, 我们由此推测, 在次生林向老龄 林的演替进程中, 生物量在个体水平和群落水平都 将有显著增长。

综上, 本研究显示人类干扰对古田山的常绿阔 叶林产生了多角度的影响: 亚热带常绿阔叶林在受 到干扰后, 次生林整体的物种组成和功能组成恢复 较快, 但就不同垂直层次而言, 其灌木层和乔木层 的物种组成特征仍与老龄林有差异; 并且次生林植 株密度和地上部分生物量等群落结构特征与老龄 林也有显著差异。因此, 次生林在演替后期可能会 减少部分物种和功能 $\alpha$ 多样性, 将补充更典型的常 绿阔叶林优势种, 形成更低的植株密度, 并提高地 上部分生物量。

致谢: 浙江大学王月霞、骆杨青等同学参与古田山 野外调查、数据录入等工作, 郑朝宗教授对植物识 别进行指导, 仲磊和巫东豪博士生对本文数据分析 提供宝贵建议; 赖正标、赖祯熙等师傅在野外调查 工作中付出辛勤劳动, 在此致谢。同时, 向附录引 用的地上生物量计算公式的研究者致谢!

\section{参考文献}

Aiba S, Hill DA, Agetsuma N (2001) Comparison between old-growth stands and secondary stands regenerating after clear-felling in warm-temperate forests of Yakushima, southern Japan. Forest Ecology and Management, 140, 163-175.

Ali A, Yan ER, Chen HY, Zhao YT, Yang XD, Xu MS (2016) Relative contribution of stand characteristics on carbon stocks in subtropical secondary forests in Eastern China. Biogeosciences, 13, 4627-4635.

Bao WK, Liu ZG (2002) Community features of the primary and naturally secondary evergreen broad-leaved forests in Mt. Wawu in Sichuan, China. Chinese Journal of Applied and Environmental Biology, 8, 120-126. (in Chinese with English abstract) [包维楷, 刘照光 (2002) 四川瓦屋山原 生和次生常绿阔叶林的群落学特征. 应用与环境生物学 报, 8, 120-126.]

Bartoń K (2017) MuMIn: Multi-Model Inference. R package version 1.42.1. https://CRAN.R-project.org/package=MuMIn. (accessed on 2019-02-25)

Baselga A (2012) The relationship between species replacement, dissimilarity derived from nestedness, and nestedness. Global Ecology \& Biogeography, 21, 1223-1232.

Biswas SR , Mallik AU (2010) Disturbance effects on species diversity and functional diversity in riparian and upland plant communities. Ecology, 91, 28-35.

Borcard D, Gillet F, Legendre P (translated by Lai JS) (2011) Numerical Ecology with R. Higher Education Press, Beijing. (in Chinese) [赖江山(译) (2014) 数量生态学: R语言的应 用. 高等教育出版社, 北京.]

Bruelheide B, Hobhnke M, Both S, Tang F, Assmann T, Baruffol M, Bauhus J, Buscot F, Chen XY, Ding BY, Durka W, Erfmeier A, Fischer M, Geißler C, Guo DL, Guo LD, Härdtle W, He JS, Hector A, Kröber W, Kühn P, Lang AC, Nadrowski K, Pei KQ, Scherer-Lorenzen M, Shi XZ, Scholten T, Schuldt A, Trogisch S, von Oheimb G, Welk E, Wirth C, Wu YT, Yang XF, Zeng XQ, Zhang SR, Zhou HZ, Ma KP, Schmid B (2011) Community assembly during secondary forest succession in a Chinese subtropical forest. Ecological Monographs, 81, 25-41.

Cardinale BJ, Matulich KL, Hooper DU, Byrnes JE, Duffy E, Gamfeldt L, Balvanera P, O’Connor MI, Gonzalez A (2011) The functional role of producer diversity in ecosystems. American Journal of Botany, 98, 572-592.

Chazdon RL, Letcher SG, Van Breugel M, Martínez-Ramos M, Bongers F, Bryan F (2007) Rates of change in tree communities of secondary Neotropical forests following major disturbances. Philosophical Transactions of the Royal Society B: Biological Sciences, 362, 273-289.

Ding Y, Zang RG, Letcher SR, Liu SR, He FL (2012) Disturbance regime changes the trait distribution, phylogenetic structure and community assembly of tropical rain forests. Oikos, 121, 1263-1270.

Editorial Board of Kaihua Forests (1988) Forestry Chorography in Kaihua County. Zhejiang People's Publishing House, Hangzhou. (in Chinese) [开化林业志编写组 (1988) 开化 林业志. 浙江人民出版社, 杭州.]

Feng G, Ai XR, Yao L, Liu JC, Huang YT, Lin Y (2016) Dynamics of natural restoration of subtropical evergreen-deciduous broadleaved mixed forests in southwest Hubei Province and influencing factors. Scientia Silvae Sinicae, 52(8), 1-9. (in Chinese with English abstract) [冯广, 艾训 儒, 姚兰, 刘峻城, 黄永涛, 林勇 (2016) 鄂西南亚热带 常绿落叶阔叶混交林的自然恢复动态及其影响因素. 林 业科学, 52(8), 1-9.]

Feng G, Svenning JC, Mi XC, Jia Q, Rao MD, Ren HB, Bebber 
DP, Ma KP (2014) Anthropogenic disturbance shapes phylogenetic and functional tree community structure in a subtropical forest. Forest Ecology \& Management, 313, 188-198.

Gower JC (1971) A general coefficient of similarity and some of its properties. Biometrics, 27, 857-871.

Hu G, Jin Y, Liu JL, Yu MJ (2014) Functional diversity versus species diversity: Relationships with habitat heterogeneity at multiple scales in a subtropical evergreen broad-leaved forest. Ecological Research, 29, 897-903.

Hu ZH, Yu MJ, Ding BY, Fang T, Qian HY, Chen QC (2003) Types of evergreen broad-leaved forests and their species diversity in Gutian Mountain National Nature Reserve. Chinese Journal of Applied and Environmental Biology, 9, 341-345. (in Chinese with English abstract) [胡正华, 于明 坚, 丁炳扬, 方腾, 钱海源, 陈启瑺 (2003) 古田山国家 级自然保护区常绿阔叶林类型及其群落物种多样性研究. 应用与环境生物学报, 9, 341-345.]

Huang B (2012) Rarefaction and its application to the study of diversity of palaeocommunties. Acta Palaeontologica Sinica, 51, 200-208. (in Chinese with English abstract) [黄冰 (2012) 浅谈稀疏标准化方法(Rarefaction)及其在群落多 样性研究中的应用. 古生物学报, 51, 200-208.]

Huang YT, Zhang X, Zang RG, Fu SL, Ai XR, Yao L, Ding Y, Huang JH, Lu XH (2018) Functional recovery of a subtropical evergreen-deciduous broadleaved mixed forest following clear cutting in Central China. Scientific Reports, 8, 16458.

Jin Y, Russo SE, Yu MJ (2018) Effects of light and topography on regeneration and coexistence of evergreen and deciduous tree species in a Chinese subtropical forest. Journal of Ecology, 106, 1634-1645.

Laliberté E, Legendre P (2010) A distance-based framework for measuring functional diversity from multiple traits. Ecology, 91, 299-305.

Laliberté E, Legendre P, Shipley B (2014) FD: Measuring functional diversity from multiple traits, and other tools for functional ecology. R package version 1.0-12. https://CRAN. R-project.org/package=FD/. (accessed on 2019-02-25)

Li QK, Ma KP (2002) Advances in plant succession ecophysiology. Acta Phytoecologica Sinica, 26(Suppl.), 9-19. (in Chinese with English abstract) [李庆康, 马克平 (2002) 植 物群落演替过程中植物生理生态学特性及其主要环境因 子的变化. 植物生态学报, 26(增刊), 9-19.]

Lin DM, Lai JS, Muller-Landau HC, Mi XC, Ma KP (2012) Topographic variation in aboveground biomass in a subtropical evergreen broad-leaved forest in China. PLoS ONE, 7, e48244.

Lin DM, Pang M, Lai JS, Mi XC, Ren HB, Ma KP (2017) Multivariate relationship between tree diversity and aboveground biomass across tree strata in a subtropical evergreen broad-leaved forest. Chinese Science Bulletin, 17, 18611868. (in Chinese with English abstract) [林敦梅, 庞梅, 赖
江山, 米湘成, 任海保, 马克平 (2017) 亚热带常绿阔叶 林不同林层物种多样性与地上生物量的多变量关系. 科 学通报, 17, 1861-1868.]

Liu JL, Qian H, Jin Y, Wu CP, Chen JH, Yu SQ, Wei XL, Jin XF, Liu JJ, Yu MJ (2016) Disentangling the drivers of taxonomic and phylogenetic beta diversities in disturbed and undisturbed subtropical forests. Scientific Reports, 6, 35926.

Lou LH, Jin SH (2000) Spermatophyta flora of Gutianshan Nature Reserve in Zhejiang. Journal of Beijing Forestry University, 22(5), 33-39. (in Chinese with English abstract) [楼炉焕, 金水虎 (2000) 浙江古田山自然保护区种子植 物区系分析. 北京林业大学学报, 22(5), 33-39.]

Lu W, Yu JP, Ren HB, Mi XC, Chen JH, Ma KP (2018) Spatial variations in species diversity of mid-subtropical evergreen broad-leaved forest community in Gutianshan National Nature Reserve. Biodiversity Science, 26, 1023-1028. (in Chinese with English abstract) [芦伟, 余建平, 任海保, 米 湘成，陈建华，马克平 (2018) 古田山中亚热带常绿阔叶 林群落物种多样性的空间变异特征. 生物多样性, 26, 1023-1028.]

Matthew JV (2012) fossil: Palaeoecological and Palaeogeographical Analysis Tools. R package version 0.3.7. https: //CRAN.R-project.org/package=fossil/. (accessed on 201902-25)

Martin PH, Sherman RE, Fahey TJ (2004) Forty years of tropical forest recovery from agriculture: Structure and floristics of secondary and old-growth riparian forests in the Dominican Republic. Biotropica, 36, 297-317.

Nong Y, Lu LH, You JH, Lei LQ, Wang YN, Li H, Yang GF (2018) The plant diversity and biomass of trees in different successional stages of secondary forest of south subtropical. Journal of Central South University of Forestry \& Technology, 38(12), 83-88. (in Chinese with English abstract) [农 友, 卢立华, 游建华, 雷丽群, 王亚南, 李华, 杨桂芳 (2018) 南亚热带不同演替阶段次生林植物多样性及乔木 生物量. 中南林业科技大学学报, 38(12), 83-88.]

Oksanen J, Blanchet FG, Kindt R, Legendre P, Minchin PR, O’Hara RB, Simpson GL, Solymos P, Stevens MHH, Wagner H (2016) vegan: Community Ecology Package. R package Version 2.3-4. https:/CRAN.R-project.org/package=vegan/. (accessed on 2019-02-25)

Pregitzer KS, Euskirchen ES (2010) Carbon cycling and storage in world forests: Biome patterns related to forest age. Global Change Biology, 10, 2052-2077.

Purschke O, Schmid BC, Sykes MT, Poschlod P, Michalski SG, Durka W, Kühn I, Winter M, Prentice HC (2013) Contrasting changes in taxonomic, phylogenetic and functional diversity during a long-term succession: Insights into assembly processes. Journal of Ecology, 101, 857-866.

Qian HY, Zhang TT, Chen SW, Wu DH, Wu CP, Yuan WG, Jin Y, Yu MJ (2018) Community structures and biodiversities of broad-leaved forest and two types of plantations in Gutianshan National Nature Reserve, Zhejiang Province. 
Guihaia, 38, 115-125. (in Chinese with English abstract) [钱 海源, 张田田, 陈声文, 巫东豪, 吴初平, 袁位高, 金毅. 于明坚 (2018) 古田山自然保护区阔叶林与两种人工林 的群落结构和生物多样性. 广西植物, 38, 115-125.]

R Core Team (2016) R: A language and environment for statistical computing. R Foundation for Statistical Computing, Vienna, Austria. https://www.r-project.org/. (accessed on 2019-02-25)

R` Ehounková K Prach K (2010) Life-history traits and habitat preferences of colonizing plant species in long-term spontaneous succession in abandoned gravel-sand pits. Basic and Applied Ecology, 11, 45-53.

Revell LJ (2012) phytools: An R Package for Phylogenetic Comparative Biology (and other things), https://CRAN.Rproject.org/package=phytools/. (accessed on 2019-02-25)

Shang KK, Zhang QP, Da LJ, Hara K, Yang YC, Fujihara M, Tomita M, Zhao Y (2014) Effects of natural and artificial disturbance on landscape and forest structure in Tiantong National Forest Park, East China. Landscape and Ecological Engineering, 10, 163-172.

Shi JN, Li W, Meng JH (2016) A comparison between tropical primary and secondary forests on Hainan Island. Chinese Journal of Applied and Environmental Biology, 22, 271-276. (in Chinese with English abstract) [史景宁, 李微, 孟京辉 (2016) 海南岛热带原始天然林和次生林对比分 析. 应用与环境生物学报, 22, 271-276.]

Song GM, Han TT, Hong L, Zhang LL, Li XB, Ren H (2018) Advances in the studies of plant functional traits during succession. Ecological Science, 37, 207-213. (in Chinese with English abstract) [宋光满, 韩涛涛, 洪岗, 张玲玲, 李 晓波, 任海 (2018) 演替过程中植物功能性状研究进展. 生态科学, 37, 207-213.]

Song K, Mi XC, Jia Q, Ren HB, Bebber D, Ma KP (2011) Variation in phylogenetic structure of forest communities along a human disturbance gradient in Gutianshan forest, China. Biodiversity Science, 19, 190-196. (in Chinese with English abstract) [宋凯, 米湘成, 贾琪, 任海保, Bebber D, 马克平 (2011) 不同程度人为干扰对古田山森林群落谱 系结构的影响. 生物多样性, 19, 190-196.]

Song YC (2013) Evergreen Broad-leaved Forests in China. Science Press, Beijing. (in Chinese) [宋永昌 (2013) 中国 常绿阔叶林. 科学出版社, 北京.]

Song YC (2016) Vegetation Ecology, 2nd edn. Higher Education Press, Beijing. (in Chinese) [宋永昌 (2016) 植被生态 学(第二版). 高等教育出版社, 北京.]

Song YC, Chen XY, Wang XH (2005) Study on evergreen broad-leaved forests of China: A retrospect and prospect. Journal of East China Normal University (Natural Science), (1), 1-8. (in Chinese with English abstract) [宋永昌, 陈小 勇, 王希华 (2005) 中国常绿阔叶林研究的回顾与展望.
华东师范大学学报(自然科学版), (1), 1-8.]

Stein A, Gerstner K, Kreft H (2014) Environmental heterogeneity as a universal driver of species richness across taxa, biomes and spatial scales. Ecology Letters, 17, 866-880.

Wang XH (2006) The Phytogeography and Species Diversity of Typical Evergreen Broad-leaved Forest in China. PhD dissertation, East China Normal University, Shanghai. (in Chinese with English abstract) [王希华 (2006) 中国典型 常绿阔叶林植物地理与物种多样性研究. 博士学位论文, 华东师范大学, 上海.]

Wang XH, Kent M, Fang XF (2007) Evergreen broad-leaved forest in Eastern China: Its ecology and conservation and the importance of resprouting in forest restoration. Forest Ecology and Management, 245, 76-87.

Wu YY, Guo CZ, Ni J (2014) Dynamics of major forest vegetations in Tiantong National Forest Park during the last 30 years. Chinese Journal of Applied Ecology, 25, 1547-1554. (in Chinese with English abstract) [吴洋洋, 郭纯子, 倪健 (2014) 天童国家森林公园主要森林植被过去30年的动态 变化. 应用生态学报, 25, 1547-1554.]

Wu ZY (1980) Vegetation of China. Science Press, Beijing. (in Chinese) [吴征镒 (1980) 中国植被. 科学出版社, 北京.]

Xu XH, Yu MJ, Hu ZH, Li MH, Zhang FG (2005) The structure and dynamics of Castanopsis eyrei population in Gutian Mountain Nature Reserve in Zhejiang, East China. Acta Ecologica Sinica, 25, 645-653. (in Chinese with English abstract) [徐学红, 于明坚, 胡正华, 李铭红, 张方 钢 (2005) 浙江古田山自然保护区甜槠种群结构与动态. 生态学报, 2, 645-653.]

Xu YJ, Lin DM, Mi XC, Ren HB, Ma KP (2014) Recovery dynamics of secondary forests with different disturbance intensity in the Gutianshan National Nature Reserve. Biodiversity Science, 22, 358-365. (in Chinese with English abstract) [徐远杰, 林敦梅, 米湘成, 任海保, 马克平 (2014) 古田山不同干扰程度森林的群落恢复动态. 生物 多样性, 22, 358-365.]

Yu MJ, Hu ZH, Yu JP, Ding BY, Fang T (2001) Forest vegetation types in Gutianshan Nature Reserve in Zhejiang. Journal of Zhejiang University (Agriculture and Life Science), 27, 375-380. (in Chinese with English abstract) [于明坚, 胡正华, 余建平, 丁炳扬, 方腾 (2001) 浙江古田山自然 保护区森林植被类型. 浙江大学学报(农业与生命科学 版), 27, 375-380.]

Yu MJ, Qian HY, Yu JP (2019) Research of Biodiversity in Gutianshan. Zhejiang Science and Technology Press, Hangzhou (in press). (in Chinese) [于明坚, 钱海源, 余建平 (2019) 古田山生物多样性研究. 浙江科学技术出版社, 杭州(排版中).]

(责任编委: 米湘成 责任编辑: 黄祥忠) 


\section{附录 Supplementary Material}

\section{附录1＼cjkstart主要物种地上部分生物量异速生长方程}

Appendix 1 Allometric equations for aboveground biomass of main species

http://www.biodiversity-science.net/fileup/PDF/2019059-1.pdf

\section{附录2 环境因子对Shannon-Wiener指数影响的线性回归模型选择结果}

Appendix 2 Results of comparison of linear model of environmental factors effects on Shannon-Wiener index of each plot http://www.biodiversity-science.net/fileup/PDF/2019059-2.pdf

\section{附录3 环境因子对功能离散度影响的线性回归模型选择结果}

Appendix 3 Results of comparison of linear model of environmental factors effects on functional dispersion of each plot http://www.biodiversity-science.net/fileup/PDF/2019059-3.pdf

附录4 次生与老龄常绿阔叶林3种功能性状的相对丰富度和相对多度比较

Appendix 4 Comparisons of relative richness and relative abundance of three functional traits between secondary and old-growth evergreen broad-leaved forests

http://www.biodiversity-science.net/fileup/PDF/2019059-4.pdf

\section{附录5 古田山常绿阔叶林物种组成和功能组成与环境因子的关系}

Appendix 5 Relationship between environmental factors and species composition and functional composition of evergreen broad-leaved forest in Gutianshan National Nature Reserve

http://www.biodiversity-science.net/fileup/PDF/2019059-5.pdf

附录6 环境因子对样地植株密度影响的线性回归模型选择结果

Appendix 6 Results of comparison of linear model of environmental factors effects on stem density of each plot http://www.biodiversity-science.net/fileup/PDF/2019059-6.pdf

\section{附录7＼cjkstart环境因子对样地地上部分生物量影响的线性回归模型选择结果}

Appendix 7 Results of comparison of linear model of environmental factors effects on aboveground biomass of each plot http://www.biodiversity-science.net/fileup/PDF/2019059-7.pdf

\section{附录8＼cjkstart次生林与老龄林间3种功能性状地上部分生物量所占比例的比较}

Appendix 8 Comparisons of proportion of total aboveground biomass between secondary and old-growth evergreen broad-leaved forests

http://www.biodiversity-science.net/fileup/PDF/2019059-8.pdf 
张田田, 王璇, 任海保, 余建平, 金毅, 钱海源, 宋小友, 马克平, 于明坚. 浙江古田山次生与老龄常绿阔叶林 群落特征的比较. 生物多样性, 2019, 27 (10): 1069-1080. http://www.biodiversity-

science.net/CN/10.17520/biods.2019059

附录1 主要物种地上部分生物量异速生长方程。AGB：地上部分生物量; D: 胸径; H: 树高。

Appendix 1 Allometric equations for aboveground biomass of main species. AGB, Aboveground biomass (kg); D, Diameter at breast height $(\mathrm{cm}) ; \mathrm{H}$, Tree height $(\mathrm{m})$.

\begin{tabular}{|c|c|c|c|}
\hline 物种 Species & 方程 Equations & $R^{2}$ & 参考文献 Reference \\
\hline 木荷 Schima superba & $\mathrm{AGB}=0.07103 \times\left(\mathrm{D}^{2} \times \mathrm{H}\right)^{0.91}$ & 0.96 & Lin et al, 2012 \\
\hline 马尾松 Pinus massoniana & $\mathrm{AGB}=0.1359 \times\left(\mathrm{D}^{2} \times \mathrm{H}\right)^{0.79}$ & 0.91 & Lin et al, 2012 \\
\hline 青冈 Cyclobalanopsis glauca & $\mathrm{AGB}=0.08542 \times\left(\mathrm{D}^{2} \times \mathrm{H}\right)^{0.91}$ & 0.93 & Lin et al, 2012 \\
\hline 米槠 Castanopsis carlesii & $\mathrm{AGB}=0.0453 \times \mathrm{D}^{1.716}+0.037 \times \mathrm{D}^{2.4599}+0.1565 \times \mathrm{D}^{2.2772}$ & 0.98 & Lin et al, 2012 \\
\hline 小叶青冈 Cyclobalanopsis myrsinifolia & $\mathrm{AGB}=0.1019 \times e^{0.1387 \mathrm{D}}+0.0358 \times \mathrm{D}^{2.4556}+0.3152 \times \mathrm{D}^{2.016}$ & 0.96 & Lin et al, 2012 \\
\hline 甜槠 Castanopsis eyrei & $\mathrm{AGB}=0.06491 \times\left(\mathrm{D}^{2} \times \mathrm{H}\right)^{0.92}$ & 0.98 & Lin et al, 2012 \\
\hline 石栋 Lithocarpus glaber & $\mathrm{AGB}=0.04268 \times\left(\mathrm{D}^{2} \times \mathrm{H}\right)^{0.98}$ & 0.99 & Lin et al, 2012 \\
\hline 栎属 Quercus & $\mathrm{AGB}=0.1199 \times\left(\mathrm{D}^{2} \times \mathrm{H}\right)^{0.8509}$ & 0.99 & Lin et al, 2012 \\
\hline 拟赤杨 Alniphyllum fortunei & $\begin{array}{l}\mathrm{AGB}=0.8003 \times\left(\mathrm{D}^{2} \times \mathrm{H}\right)^{0.5276}+0.1768 \times\left(\mathrm{D}^{2} \times \mathrm{H}\right)^{0.5648}+0.564 \\
\times\left(\mathrm{D}^{2} \times \mathrm{H}\right)^{0.3191}\end{array}$ & 0.95 & Lin et al, 2012 \\
\hline 皪木 Loropetalum chinense & $\mathrm{AGB}=0.1599 \times \mathrm{D}^{2.35119}$ & 0.99 & Lin et al, 2012 \\
\hline 马银花 Rhododendron ovatum & $\mathrm{AGB}=0.3323 \times \mathrm{D}^{1.7874}$ & 0.96 & Lin et al 2012 \\
\hline 鹿角杜鹃 Rhododendron latoucheae & $\mathrm{AGB}=0.2212 \times \mathrm{D}^{1.9932}$ & 0.92 & Lin et al, 2012 \\
\hline 其他物种 Other species & $\mathrm{AGB}=0.09459 \times\left(\mathrm{D}^{2} \times \mathrm{H}\right)^{0.87}$ & 0.91 & Lin et al, 2012 \\
\hline 杉木 Cunninghamia lanceolata & $\mathrm{AGB}=0.0508 \times \mathrm{D}^{2.665}$ & 0.952 & Chen et al, 2013 \\
\hline 栲 Castanopsis fargesii & $\mathrm{AGB}=0.05115184 \times\left(\mathrm{D}^{2} \times \mathrm{H}\right)^{0.9280}$ & 0.998 & 杨同辉等, 2007 \\
\hline 细叶青冈 Cyclobalanopsis gracilis & $\mathrm{AGB}=0.08151426 \times\left(\mathrm{D}^{2} \times \mathrm{H}\right)^{0.9598}$ & 0.998 & 杨同辉等, 2007 \\
\hline 苦槠 Castanopsis sclerophylla & $\mathrm{AGB}=0.060143 \times\left(\mathrm{D}^{2} \times \mathrm{H}\right)^{0.9274}$ & 0.961 & 刘其霞等, 2005 \\
\hline 枫香树 Liquidambar formosana & $\mathrm{AGB}=0.034514 \times\left(\mathrm{D}^{2} \times \mathrm{H}\right)^{1.0037}$ & 0.955 & 刘其霞等, 2005 \\
\hline 格药柃 Eurya muricata & $\mathrm{AGB}=0.7059 \times 0.313375 \times \pi \times \mathrm{D}^{2}$ & 0.939 & Ali et al, 2014 \\
\hline 窄基红褐柃 Eurya rubiginosa var. attenuata & $\mathrm{AGB}=0.7 \times 0.30405 \times \pi \times \mathrm{D}^{2}$ & 0.964 & Ali et al, 2014 \\
\hline 毛花连莣茶 Camellia trichoclada & $\mathrm{AGB}=0.7234 \times 0.30405 \times \pi \times \mathrm{D}^{2}$ & 0.914 & Ali et al, 2014 \\
\hline 老鼠矢 Symplocos stellaris & $\mathrm{AGB}=0.7848 \times\left(-1+0.39728 \times \pi \times \mathrm{D}^{2}\right)$ & 0.926 & Ali et al, 2014 \\
\hline 山矾 Symplocos sumuntia & $\mathrm{AGB}=0.7797 \times 0.2062 \times \pi \times \mathrm{D}^{2}$ & 0.942 & Ali et al, 2014 \\
\hline 江南越桔 Vaccinium mandarinorum & $\mathrm{AGB}=0.7 \times 0.29192 \times \pi \times \mathrm{D}^{2}$ & 0.978 & Ali et al, 2014 \\
\hline 杨梅 Myrica rubra & $\mathrm{AGB}=0.7 \times\left(-6+1.35732 \times \pi \times \mathrm{D}^{2}\right)$ & 0.997 & Ali et al, 2014 \\
\hline 赤楠 Syzygium buxifolium & $\mathrm{AGB}=0.7 \times\left(0.04+0.28075 \times \pi \times \mathrm{D}^{2}\right)$ & 0.947 & Ali et al, 2014 \\
\hline 钩栲 Castanopsis tibetana & $\mathrm{AGB}=0.094 \times\left(\mathrm{D}^{2} \times \mathrm{H}\right)^{0.8799}$ & 0.97 & 左舒翟等, 2015 \\
\hline 猴欢喜 Sloanea sinensis & $\mathrm{AGB}=0.1614 \times\left(\mathrm{D}^{2} \times \mathrm{H}\right)^{0.7802}$ & 0.92 & 左舒翟等, 2015 \\
\hline 虎皮楠 Daphniphyllum oldhami & $\mathrm{AGB}=0.0975 \times\left(\mathrm{D}^{2} \times \mathrm{H}\right)^{0.8657}$ & 0.94 & 左舒翟等, 2015 \\
\hline 乳源木莲 Manglietia fordiana & $\mathrm{AGB}=0.0584 \times\left(\mathrm{D}^{2} \times \mathrm{H}\right)^{0.9003}$ & 0.95 & 左舒翟等, 2015 \\
\hline 杨桐 Adinandra millettii & $\mathrm{AGB}=e^{(-3.83+1.99 \times \operatorname{Ln}(\mathrm{D})+0.860 \times \operatorname{Ln}(\mathrm{H}))}$ & 0.99 & Ali et al, 2015 \\
\hline 柿 Diospyros kaki & $\mathrm{AGB}=e^{(-5.57+1.89 \times \operatorname{Ln}(\mathrm{D})+1.16 \times \operatorname{Ln}(\mathrm{H})+2.72 \times 0.53)}$ & 0.99 & Ali et al, 2015 \\
\hline 红楠 Machilus thunbergii & $\mathrm{AGB}=e^{(-3.51+2.59 \times \operatorname{Ln}(\mathrm{D}))}$ & 0.99 & Ali et al, 2015 \\
\hline 褐叶青冈 Cyclobalanopsis stewardiana & $\mathrm{AGB}=e^{(-3.67+3.07 \times \operatorname{Ln}(\mathrm{D}))}$ & 0.98 & Ali et al, 2015 \\
\hline 樟 Cinnamomum camphora & $\mathrm{AGB}=0.175374 \times\left(\mathrm{D}^{2} \times \mathrm{H}\right)^{0.819874}-0.184736 \times\left(\mathrm{D}^{2} \times \mathrm{H}\right)^{0.616421}$ & 0.96 & 姚迎九等, 2003 \\
\hline 水杉 Metasequoia glyptostroboides & $\mathrm{AGB}=0.06291 \times \mathrm{D}^{2.4841}$ & 0.972 & 庄红蕾等, 2012 \\
\hline
\end{tabular}

\section{参考文献}

Ali A, Ma WJ, Yang XD, Sun BW, Xu MS (2014) Biomass and carbon stocks in schima superba dominated subtropical 
张田田，王璇，任海保，余建平，金毅，钱海源，宋小友，马克平，于明坚. 浙江古田山次生与老龄常绿阔叶林 群落特征的比较. 生物多样性, 2019, 27 (10): 1069-1080. http://www.biodiversity-

science.net/CN/10.17520/biods.2019059

forests of eastern china. Journal of Forest Science, 60, 198-207.

Ali A, Xu MS, Zhao YT, Zhang QQ, Zhou LL, Yang XD, Yan ER (2015) Allometric biomass equations for shrub and small tree species in subtropical China. Silva Fennica. 49, 1-10.

Chen GS, Yang ZJ, Gao R, Xie JS, Guo JF, Huang ZQ, Yang YS (2013) Carbon storage in a chronosequence of chinese fir plantations in southern china. Forest Ecology and Management, 300, 68-76.

Lin DM, Lai JS, Muller-Landau HC, Mi XC, Ma KP (2012) Topographic Variation in Aboveground Biomass in a Subtropical Evergreen Broad-Leaved Forest in China. PLoS ONE, 7(10), e48244.

Liu QX, Chang J, Jiang B, Yuan WG, Qi LZ, Zhu JR, Ge Y, Shen Q (2005) The biomass of the evergreen broad-leaved ecological public-welfare forests in Zhejiang, East China. Acta Ecologica Sinica, 25, 11-16. (in Chinese with English abstract) [刘其霞, 常杰, 江波, 袁位高, 戚连忠, 朱锦茹, 葛滢, 沈琪 (2005) 浙江省常绿阔叶生态 公益林生物量. 生态学报, 25, 11-16.]

Yang TH, Da LJ, Song K, Li XP (2007) Study on the correlation between volume and biomass of main tree species in the evergreen broad2leaved forest of Tiantong National Forest Park, Zhejiang Province. Journal of Fujian Forestry Science and Technology, 34, 110-112. (in Chinese with English abstract) [杨同辉，达良俊，宋坤，李修鹏 (2007) 浙江天童国家森林公园常绿阔叶林主要组成树种材积与生物量相关关系探讨. 福建林业科技, 34, 110-112.]

Yao YJ, Kang WX, Tian DL Study of the Biomass and Productivity of Cinnamomum camphora Plantation. Journal of Central South Forestry University, 23, 1-5. (in Chinese with English abstract) [姚迎九，康文星，田大伦 (2003) 18 年生樟树人工林生物量的结构与分布. 中南林业科技大学学报, 23, 1-5.]

Zhuang HL, Becuwe X, Xiao CB, Wang YH, Wang H, Yin S, Liu CJ (2012) Allometric Equation-Based Estimation of Biomass Carbon Sequestration in Metasequoia glyptostroboides Plantations in Chongming Island,Shanghai, Journal of Shanghai Jiaotong University(Agricultrual Science), 30(2), 48-55. (in Chinese with English abstract) [庄红蕾, Xavier Becuwe, 肖春波, 王月华, 王海, 殷杉, 刘春江 (2012) 上海崇明岛水杉人工林生物量方 程构建及固碳潜力研究. 上海交通大学学报(农业科学版), 30(2), 48-55.]

Zuo SZ, Ren Y, Weng X, Ding HF, Luo YJ (2015) Biomass allometric equations of nine common tree species in an evergreen broadleaved forest of subtropical China. Chinese Journal of Applied Ecology, 26, 356-362. (in Chinese with English abstract) [左舒翟, 任引, 翁闲, 丁洪峰, 罗云建 (2015) 亚热带常绿阔叶林 9 个常见树种的生 物量相对生长模型. 应用生态学报, 26, 356-362.] 
张田田, 王璇, 任海保, 余建平, 金毅, 钱海源, 宋小友, 马克平, 于明坚. 浙江古田山次生与老龄常绿阔叶林 群落特征的比较. 生物多样性, 2019, 27 (10): 1069-1080. http://www.biodiversity-

science.net/CN/10.17520/biods.2019059

附录2 环境因子对Shannon-Wiener指数影响的线性回归模型选择结果。最优模型以粗体标出。AICc, 根据样 本数量修正过后的AIC值; delta, 模型与AICc 最小模型间的AICc值差异; weight, 模型为最优模型的概率。

Appendix 2 Results of comparison of linear model of environmental factors effects on Shannon-Wiener index of each plot. The best supported model is in bold. AICc, AIC corrected by limited sample size; delta, difference in AICc between the model and the parsimonious model; weight, possibility of the model being the best supported model.

\begin{tabular}{|c|c|c|c|c|c|c|c|c|c|}
\hline & 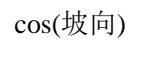 & 海拔 & $\sin ($ 坡向) & 坡度 & 人类干扰 & 自由度 & $\mathrm{AICc}$ & delta & weight \\
\hline Intercept & $\cos$ (Aspect) & Elevation & $\sin ($ Aspect $)$ & Slope & Human disturbance & $d f$ & & & \\
\hline 20.06 & -4.658 & & & & 10.27 & 4 & 208.8 & o & 0.252 \\
\hline 26.66 & -5.208 & & & -0.148 & 9.153 & 5 & 209.4 & 0.6 & 0.187 \\
\hline 13.43 & -4.994 & 0.0106 & & & 10.37 & 5 & 210.3 & 1.49 & 0.12 \\
\hline 22.95 & & & & & 7.919 & 3 & 211.1 & 2.26 & 0.081 \\
\hline 20.09 & -4.655 & & 0.137 & & 10.26 & 5 & 211.7 & 2.94 & 0.058 \\
\hline 21.51 & -5.303 & 0.0063 & & -0.120 & 9.423 & 6 & 212.2 & 3.36 & 0.047 \\
\hline 26.81 & -5.207 & & 0.378 & -0.149 & 9.107 & 6 & 212.6 & 3.78 & 0.038 \\
\hline 27.75 & & & & -0.102 & 6.954 & 4 & 212.8 & 4.02 & 0.034 \\
\hline 18.39 & & 0.0075 & & & 7.871 & 4 & 213.1 & 4.35 & 0.029 \\
\hline 13.33 & -5 & 0.0107 & -0.179 & & 10.39 & 6 & 213.5 & 4.69 & 0.024 \\
\hline 23 & & & 0.218 & & 7.9 & 4 & 213.8 & 4.96 & 0.021 \\
\hline 40.43 & & & & -0.175 & & 3 & 214.6 & 5.83 & 0.014 \\
\hline 34.69 & & & & & & 2 & 214.7 & 5.88 & 0.013 \\
\hline 42.39 & -3.495 & & & -0.221 & & 4 & 214.8 & 6.05 & 0.012 \\
\hline 24.12 & & 0.0044 & & -0.082 & 7.116 & 5 & 215.6 & 6.78 & 0.009 \\
\hline 21.66 & -5.301 & 0.0062 & 0.152 & -0.121 & 9.399 & 7 & 215.7 & 6.87 & 0.008 \\
\hline 27.9 & & & 0.392 & -0.104 & 6.906 & 5 & 215.7 & 6.93 & 0.008 \\
\hline 18.39 & & 0.0075 & $-2.000 \mathrm{E}-04$ & & 7.871 & 5 & 216.1 & 7.29 & 0.007 \\
\hline 34.98 & -2.293 & & & & & 3 & 216.1 & 7.35 & 0.006 \\
\hline 29.75 & & 0.0081 & & & & 3 & 216.6 & 7.81 & 0.005 \\
\hline 34.75 & & & 0.625 & & & 3 & 217.1 & 8.32 & 0.004 \\
\hline 40.57 & & & 0.834 & -0.176 & & 4 & 217.2 & 8.43 & 0.004 \\
\hline 39.23 & & 0.0016 & & -0.168 & & 4 & 217.3 & 8.52 & 0.004 \\
\hline 42.56 & -3.514 & & 0.919 & -0.223 & & 5 & 217.6 & 8.84 & 0.003 \\
\hline 40.74 & -3.511 & 0.0022 & & -0.211 & & 5 & 217.7 & 8.95 & 0.003 \\
\hline 29.05 & -2.58 & 0.0097 & & & & 4 & 218 & 9.2 & 0.003 \\
\hline 24.36 & & 0.0043 & 0.236 & -0.084 & 7.081 & 6 & 218.8 & 9.98 & 0.002 \\
\hline 35.05 & -2.298 & & 0.645 & & & 4 & 218.8 & 9.99 & 0.002 \\
\hline 29.91 & & 0.0079 & 0.396 & & & 4 & 219.3 & 10.49 & 0.001 \\
\hline 39.78 & & 0.001 & 0.798 & -0.172 & & 5 & 220.2 & 11.36 & 0.001 \\
\hline 41.34 & -3.524 & 0.0016 & 0.864 & -0.216 & & 6 & 220.8 & 12.03 & 0.001 \\
\hline 29.2 & -2.577 & 0.01 & 0.369 & & & 5 & 220.9 & 12.12 & 0.001 \\
\hline
\end{tabular}


张田田, 王璇, 任海保, 余建平, 金毅, 钱海源, 宋小友, 马克平, 于明坚. 浙江古田山次生与老龄常绿阔叶林 群落特征的比较. 生物多样性, 2019, 27 (10): 1069-1080. http://www.biodiversity-

science.net/CN/10.17520/biods.2019059

附录3 环境因子对功能离散度影响的线性回归模型选择结果。最优模型以粗体标出。AICc, 根据样本数量修 正过后的AIC 值; delta，模型与AICc 最小模型间的AICc 值差异; weight，模型为最优模型的概率。

Appendix 3 Results of comparison of linear model of environmental factors effects on functional dispersion of each plot. The best supported model is in bold. AICc, AIC corrected by limited sample size; delta, difference in AICc between the model and the parsimonious model; weight, possibility of the model being the best supported model.

\begin{tabular}{|c|c|c|c|c|c|c|c|c|c|}
\hline $\begin{array}{l}\text { 截距 } \\
\text { Intercept }\end{array}$ & $\begin{array}{l}\cos (\text { 坡向) } \\
\cos \text { (Aspect) }\end{array}$ & $\begin{array}{l}\text { 海拔 } \\
\text { Elevation }\end{array}$ & $\begin{array}{l}\sin (\text { 坡向) } \\
\sin \text { (Aspect) }\end{array}$ & $\begin{array}{l}\text { 坡度 } \\
\text { Slope }\end{array}$ & $\begin{array}{l}\text { 人类干扰 } \\
\text { Human disturbance }\end{array}$ & $\begin{array}{l}\text { 自由度 } \\
d f\end{array}$ & $\mathrm{AICc}$ & delta & weight \\
\hline 0.194 & & $7.22 \mathrm{E}-05$ & & & 0.026 & 4 & -107.2 & $\mathbf{0}$ & 0.135 \\
\hline 0.238 & & & & & 0.026 & 3 & -106.5 & 0.67 & 0.097 \\
\hline 0.303 & & & & $-7.889 \mathrm{E}-04$ & & 3 & -105.7 & 1.47 & 0.065 \\
\hline 0.232 & & 7.38E-05 & & & & 3 & -105.5 & 1.62 & 0.06 \\
\hline 0.265 & & & & $-5.711 \mathrm{E}-04$ & 0.021 & 4 & -105.5 & 1.68 & 0.059 \\
\hline 0.199 & & $6.81 \mathrm{E}-05$ & 0.008 & & 0.025 & 5 & -105 & 2.14 & 0.046 \\
\hline 0.277 & & & & & & 2 & -105 & 2.19 & 0.045 \\
\hline 0.24 & & & 0.01 & & 0.025 & 4 & -104.9 & 2.26 & 0.044 \\
\hline 0.305 & & & 0.012 & $-8.167 \mathrm{E}-04$ & & 4 & -104.6 & 2.53 & 0.038 \\
\hline 0.215 & & $6.11 \mathrm{E}-05$ & & $-2.918 \mathrm{E}-04$ & 0.023 & 5 & -104.6 & 2.54 & 0.038 \\
\hline 0.264 & & $5.19 \mathrm{E}-05$ & & $-5.715 \mathrm{E}-04$ & & 4 & -104.4 & 2.8 & 0.033 \\
\hline 0.197 & 0.003 & 7.04E-05 & & & 0.024 & 5 & -104.3 & 2.83 & 0.033 \\
\hline 0.241 & 0.005 & & & & 0.024 & 4 & -104.1 & 3.06 & 0.029 \\
\hline 0.269 & & & 0.011 & $-6.102 \mathrm{E}-04$ & 0.02 & 5 & -104 & 3.19 & 0.028 \\
\hline 0.276 & 0.011 & & & & & 3 & -103.8 & 3.33 & 0.026 \\
\hline 0.234 & 0.009 & $6.83 \mathrm{E}-05$ & & & & 4 & -103.8 & 3.36 & 0.025 \\
\hline 0.236 & & $6.91 \mathrm{E}-05$ & 0.009 & & & 4 & -103.7 & 3.4 & 0.025 \\
\hline 0.278 & & & 0.012 & & & 3 & -103.7 & 3.44 & 0.024 \\
\hline 0.299 & 0.007 & & & $-6.998 \mathrm{E}-04$ & & 4 & -103.5 & 3.61 & 0.022 \\
\hline 0.272 & & 4.42E-05 & 0.011 & $-6.281 \mathrm{E}-04$ & & 5 & -102.7 & 4.45 & 0.015 \\
\hline 0.265 & 0.003 & & & $-5.440 \mathrm{E}-04$ & 0.02 & 5 & -102.7 & 4.5 & 0.014 \\
\hline 0.224 & & $5.41 \mathrm{E}-05$ & 0.009 & $-3.559 \mathrm{E}-04$ & 0.022 & 6 & -102.4 & 4.74 & 0.013 \\
\hline 0.277 & 0.011 & & 0.011 & & & 4 & -102.4 & 4.75 & 0.013 \\
\hline 0.244 & 0.005 & & 0.01 & & 0.023 & 5 & -102.3 & 4.86 & 0.012 \\
\hline 0.301 & 0.007 & & 0.012 & $-7.305 \mathrm{E}-04$ & & 5 & -102.2 & 4.92 & 0.012 \\
\hline 0.261 & 0.006 & $5.08 \mathrm{E}-05$ & & $-4.918 \mathrm{E}-04$ & & 5 & -101.9 & 5.21 & 0.01 \\
\hline 0.202 & 0.003 & $6.61 \mathrm{E}-05$ & 0.008 & & 0.024 & 6 & -101.9 & 5.22 & 0.01 \\
\hline 0.238 & 0.009 & $6.34 \mathrm{E}-05$ & 0.01 & & & 5 & -101.8 & 5.33 & 0.009 \\
\hline 0.216 & 0.002 & $6.04 \mathrm{E}-05$ & & $-2.761 \mathrm{E}-04$ & 0.022 & 6 & -101.5 & 5.69 & 0.008 \\
\hline 0.27 & 0.003 & & 0.011 & $-5.828 \mathrm{E}-04$ & 0.018 & 6 & -100.9 & 6.27 & 0.006 \\
\hline 0.269 & 0.006 & $4.32 \mathrm{E}-05$ & 0.011 & $-5.498 \mathrm{E}-04$ & & 6 & -100 & 7.13 & 0.004 \\
\hline 0.225 & 0.002 & 5.33E-05 & 0.009 & $-3.396 \mathrm{E}-04$ & 0.021 & 7 & -99 & 8.19 & 0.002 \\
\hline
\end{tabular}


张田田, 王璇, 任海保, 余建平, 金毅, 钱海源, 宋小友, 马克平, 于明坚. 浙江古田山次生与老龄常绿榈叶林群落特征的比较. 生物多样性, 2019, 27 (10): 1069-1080. http://www.biodiversity-science.net/CN/10.17520/biods.2019059

附录4 次生与老龄常绿阔叶林3种功能性状的相对丰富度和相对多度比较(老龄林/次生林)。*,P $<0.05 ; * *, P<0.01 ; * * *, P<0.001$

2 Appendix 4 Comparisons of relative richness and relative abundance of three functional traits between secondary and old-growth evergreen broad-leaved forests (Old-growth forests/ Secondary forests). *, $P<0.05 ; * *, P<0.01 ; * *, P<0.001$

\begin{tabular}{|c|c|c|c|c|c|c|c|c|}
\hline & \multicolumn{3}{|l|}{ 叶生活型 Leaf life forms } & \multicolumn{2}{|c|}{ 生长型 Growth forms } & \multicolumn{2}{|c|}{ 传播方式 Dispersal vector } & \multirow{2}{*}{$\begin{array}{r}6 \\
\text { 动物传播 }\end{array}$} \\
\hline & 常绿阔叶 & 落叶阔叶 & 针叶 & 乔木 & 灌木 & 自身传播 & 风力传播 & \\
\hline & Evergreen broad-leaved plant & Deciduous broad-leaved plant & Needle plant & Tree & Shrub & Autochory & Anemochory & Zoochory $_{8}$ \\
\hline 相对丰富度 & $75.71 / 66.44^{* *}$ & $21.97 / 31.44^{* *}$ & $2.08 / 3.57$ & $53.42 / 51.32$ & $46.58 / 48.68$ & $25.49 / 23.28$ & $20.59 / 17.81$ & $53.92 / 58.91^{*}$ \\
\hline Relative richness (\%) & & & & & & & & \\
\hline 相对多度 & $87.33 / 81.70$ & $11.28 / 15.75$ & 1.70/4.62 & $44.49 / 53.84$ & $50.51 / 46.16$ & $25.69 / 27.39$ & $26.94 / 20.53$ & $47.37 / 52.08$ \\
\hline Relative abundance (\%) & & & & & & & & \\
\hline
\end{tabular}


张田田，王璇，任海保，余建平，金毅，钱海源，宋小友，马克平，于明坚. 浙江古田山次生与老龄常绿阔叶 林群落特征的比较. 生物多样性, 2019, 27 (10): 1069-1080. http://www.biodiversityscience.net/CN/10.17520/biods.2019059

附录 5 古田山常绿阔叶林物种组成和功能组成与环境因子的关系。*,P<0.05; **, $P<0.01 ; * *, P<0.001$ 。 Appendix 5 Relationship between environmental factors and species composition and functional composition of evergreen broad-leaved forest in Gutianshan National Nature Reserve. *, $\mathrm{P}<0.05$; **, $\mathrm{P}<0.01$; *** $\mathrm{P}<0.001$.

12

\begin{tabular}{lll}
\hline 变量 Variables & 物种组成 Species composition & 功能组成 Functional composition \\
\hline 截距 Intercept & 0.544 & 0.131 \\
地理距离 Geographical distance & -0.001 & -0.004 \\
海拔 Elevation & $8.530 \mathrm{E}-05$ & $4.000 \mathrm{E}-07$ \\
坡度 Slope & $-3.483 \mathrm{E}-04$ & $7.350 \mathrm{E}-05$ \\
$\cos ($ 坡向) cos (Aspect) & -0.001 & -0.002 \\
$\sin ($ 坡向) $\sin$ (Aspect) & 0.01 & -0.004 \\
人类干扰 Human disturbance & $0.027^{*}$ & 0.004 \\
\hline
\end{tabular}


张田田，王璇，任海保，余建平，金毅，钱海源，宋小友，马克平，于明坚. 浙江古田山次生与老龄常绿阔叶 林群落特征的比较. 生物多样性, 2019, 27 (10): 1069-1080. http://www.biodiversityscience.net/CN/10.17520/biods.2019059

附录6 环境因子对样地植株密度影响的线性回归模型选择结果。最优模型以粗体标出。AICc, 根据样本数 量修正过后的AIC值; delta，模型与AICc 最小模型间的AICc值差异; weight，模型为最优模型的概率。

Appendix 6 Results of comparison of linear model of environmental factors effects on stem density of each plot.

18 The best supported model is in bold. AICc, AIC corrected by limited sample size; delta, difference in AICc

between the model and the parsimonious model; weight, possibility of the model be the best supported model.

20

\begin{tabular}{|c|c|c|c|c|c|c|c|c|c|}
\hline 截距 & 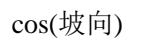 & 海拔 & $\sin$ (坡向) & 坡度 & 人类干扰 & 自由度 & $\mathrm{AICc}$ & delta & weight \\
\hline Intercept & $\cos$ (Aspect) & Elevation & $\sin ($ Aspect $)$ & Slope & Human disturbance & $d f$ & & & \\
\hline-1.491 & & & & -0.432 & 1.006 & 4 & 65.4 & $\mathbf{0}$ & 0.314 \\
\hline-1.437 & & & 0.201 & -0.448 & 0.969 & 5 & 65.4 & 0 & 0.314 \\
\hline-1.396 & & -0.109 & 0.217 & -0.497 & 0.942 & 6 & 67.8 & 2.47 & 0.092 \\
\hline-1.468 & & -0.069 & & -0.462 & 0.99 & 5 & 68 & 2.67 & 0.083 \\
\hline-1.504 & -0.015 & & & -0.435 & 1.014 & 5 & 68.3 & 2.93 & 0.073 \\
\hline-1.449 & -0.014 & & 0.201 & -0.451 & 0.977 & 6 & 68.5 & 3.2 & 0.064 \\
\hline-1.476 & -0.01 & -0.068 & & -0.464 & 0.996 & 6 & 71.2 & 5.87 & 0.017 \\
\hline-1.402 & -0.006 & -0.108 & 0.217 & -0.498 & 0.945 & 7 & 71.3 & 5.98 & 0.016 \\
\hline-1.885 & & & & & 1.271 & 3 & 72.5 & 7.2 & 0.009 \\
\hline-1.852 & & & 0.168 & & 1.249 & 4 & 73.8 & 8.46 & 0.005 \\
\hline-1.878 & & 0.114 & & & 1.267 & 4 & 74.6 & 9.25 & 0.003 \\
\hline-1.821 & 0.065 & & & & 1.228 & 4 & 75.1 & 9.72 & 0.002 \\
\hline $7.67 \mathrm{E}-17$ & & & 0.242 & -0.604 & & 4 & 75.7 & 10.36 & 0.002 \\
\hline $7.02 \mathrm{E}-17$ & & & & -0.592 & & 3 & 75.7 & 10.39 & 0.002 \\
\hline-1.849 & & 0.095 & 0.157 & & 1.247 & 5 & 76.3 & 10.94 & 0.001 \\
\hline-1.785 & 0.068 & & 0.169 & & 1.204 & 5 & 76.5 & 11.19 & 0.001 \\
\hline $7.53 \mathrm{E}-17$ & & -0.177 & 0.267 & -0.677 & & 5 & 77.4 & 12.02 & 0.001 \\
\hline-1.830 & 0.049 & 0.107 & & & 1.234 & 5 & 77.4 & 12.09 & 0.001 \\
\hline $6.95 \mathrm{E}-17$ & 0.128 & & & -0.557 & & 4 & 77.8 & 12.41 & 0.001 \\
\hline $6.86 \mathrm{E}-17$ & & -0.132 & & -0.645 & & 4 & 77.8 & 12.44 & 0.001 \\
\hline $7.60 \mathrm{E}-17$ & 0.123 & & 0.239 & -0.571 & & 5 & 78 & 12.61 & 0.001 \\
\hline-1.795 & 0.054 & 0.088 & 0.159 & & 1.21 & 6 & 79.4 & 14.01 & 0 \\
\hline $7.44 \mathrm{E}-17$ & 0.128 & -0.181 & 0.265 & -0.644 & & 6 & 79.8 & 14.44 & 0 \\
\hline $6.78 \mathrm{E}-17$ & 0.133 & -0.137 & & -0.611 & & 5 & 80 & 14.62 & 0 \\
\hline$-3.35 \mathrm{E}-17$ & & & & & & 2 & 85.7 & 20.39 & 0 \\
\hline$-2.21 \mathrm{E}-17$ & 0.278 & & & & & 3 & 85.9 & 20.57 & 0 \\
\hline$-2.97 \mathrm{E}-17$ & & & 0.211 & & & 3 & 86.9 & 21.57 & 0 \\
\hline$-1.84 \mathrm{E}-17$ & 0.276 & & 0.209 & & & 4 & 87.2 & 21.87 & 0 \\
\hline$-2.30 \mathrm{E}-17$ & & 0.127 & & & & 3 & 87.8 & 22.42 & 0 \\
\hline$-1.51 \mathrm{E}-17$ & 0.265 & 0.09 & & & & 4 & 88.4 & 23.02 & 0 \\
\hline$-2.14 \mathrm{E}-17$ & & 0.103 & 0.199 & & & 4 & 89.3 & 23.96 & 0 \\
\hline$-1.35 \mathrm{E}-17$ & 0.267 & 0.066 & 0.201 & & & 5 & 90 & 24.67 & 0 \\
\hline
\end{tabular}


张田田，王璇，任海保，余建平，金毅，钱海源，宋小友，马克平，于明坚. 浙江古田山次生与老龄常绿阔叶 林群落特征的比较. 生物多样性, 2019, 27 (10): 1069-1080. http://www.biodiversityscience.net/CN/10.17520/biods.2019059

附录7 环境因子对样地地上部分生物量影响的线性回归模型选择结果。最优模型以粗体标出。AICc, 根据 样本数量修正过后的AIC值; delta, 模型与 AICc 最小模型间的AICc值差异; weight, 模型为最优模型的概 率。

Appendix 7 Results of comparison of linear model of environmental factors effects on aboveground biomass of each plot. The best supported model is in bold. AICc, AIC corrected by limited sample size; delta, difference in AICc between the model and the parsimonious model; weight, possibility of the model be the best supported model.

\begin{tabular}{|c|c|c|c|c|c|c|c|c|c|}
\hline $\begin{array}{l}\text { 截距 } \\
\text { Intercept }\end{array}$ & 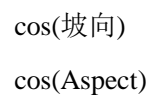 & $\begin{array}{l}\text { 海拔 } \\
\text { Elevation }\end{array}$ & $\begin{array}{l}\sin (\text { 坡向) } \\
\sin \text { (Aspect) }\end{array}$ & $\begin{array}{l}\text { 坡度 } \\
\text { Slope }\end{array}$ & $\begin{array}{l}\text { 人类干扰 } \\
\text { Human disturbance }\end{array}$ & $\begin{array}{l}\text { 自由度 } \\
d f\end{array}$ & $\mathrm{AICc}$ & delta & weight \\
\hline 7,231 & & 6.135 & & & $-2,882$ & 4 & 545.7 & o & 0.282 \\
\hline 10,930 & & & & & $-2,843$ & 3 & 547 & 1.33 & 0.145 \\
\hline 13,050 & & & & -45.09 & $-3,267$ & 4 & 548 & 2.3 & 0.089 \\
\hline 7,001 & & 6.352 & -437.3 & & $-2,845$ & 5 & 548.2 & 2.57 & 0.078 \\
\hline 8,668 & & 5.355 & & -20.62 & $-3,071$ & 5 & 548.3 & 2.6 & 0.077 \\
\hline 7,426 & 195.7 & 6.014 & & & $-2,980$ & 5 & 548.5 & 2.86 & 0.068 \\
\hline 11,170 & 385.9 & & & & $-3,038$ & 4 & 549.4 & 3.75 & 0.043 \\
\hline 10,880 & & & -253.8 & & $-2,820$ & 4 & 549.6 & 3.93 & 0.04 \\
\hline 13,090 & 225.7 & & & -43.11 & $-3,363$ & 5 & 550.8 & 5.14 & 0.022 \\
\hline 12,980 & & & -179.2 & -44.47 & $-3,246$ & 5 & 550.9 & 5.19 & 0.021 \\
\hline 8,277 & & 5.649 & -386.9 & -17.93 & $-3,014$ & 6 & 551.2 & 5.52 & 0.018 \\
\hline 3,072 & & 5.949 & & & & 3 & 551.3 & 5.62 & 0.017 \\
\hline 7,186 & 182.1 & 6.236 & -430.8 & & $-2,937$ & 6 & 551.4 & 5.7 & 0.016 \\
\hline 8,740 & 145.4 & 5.305 & & -19.57 & $-3,134$ & 6 & 551.4 & 5.77 & 0.016 \\
\hline 6,719 & & & & & & 2 & 551.7 & 6.03 & 0.014 \\
\hline 11,120 & 382.1 & & -247.1 & & $-3,014$ & 5 & 552.2 & 6.58 & 0.01 \\
\hline 2,838 & & 6.241 & -580.5 & & & 4 & 553.5 & 7.83 & 0.006 \\
\hline 2,937 & -497.9 & 6.274 & & & & 4 & 553.5 & 7.86 & 0.006 \\
\hline 2,150 & & 6.577 & & 16.33 & & 4 & 553.8 & 8.15 & 0.005 \\
\hline 13,020 & 225.3 & & -178.6 & -42.49 & $-3,341$ & 6 & 554 & 8.29 & 0.004 \\
\hline 6,681 & & -399 & & & & 3 & 554 & 8.32 & 0.004 \\
\hline 6,759 & -313.4 & & & & & 3 & 554 & 8.36 & 0.004 \\
\hline 7,089 & & & -11.23 & & & 3 & 554.1 & 8.44 & 0.004 \\
\hline 8,349 & 140.1 & 5.599 & -384.7 & -16.94 & $-3,075$ & 7 & 554.7 & 9 & 0.003 \\
\hline 2,699 & -502.7 & 6.571 & -585.7 & & & 5 & 556 & 10.29 & 0.002 \\
\hline 1,715 & & 7.015 & -626.2 & 19.57 & & 5 & 556.2 & 10.52 & 0.001 \\
\hline 2,344 & -450.6 & 6.655 & & 10.73 & & 5 & 556.4 & 10.73 & 0.001 \\
\hline 6,721 & -310.7 & & -396.3 & & & 4 & 556.5 & 10.85 & 0.001 \\
\hline 7,315 & -403.5 & & & -16.54 & & 4 & 556.5 & 10.88 & 0.001 \\
\hline 7,023 & & & -386.7 & -10.37 & & 4 & 556.6 & 10.95 & 0.001 \\
\hline 1,910 & -441.1 & 7.086 & -617.9 & 14.04 & & 6 & 559 & 13.37 & 0 \\
\hline 7,247 & -395.8 & & -377.1 & -15.59 & & 5 & 559.3 & 13.63 & 0 \\
\hline
\end{tabular}


张田田, 王璇, 任海保, 余建平, 金毅, 钱海源, 宋小友, 马克平, 于明坚. 浙江古田山次生与老龄常绿阔叶 林群落特征的比较. 生物多样性, 2019, 27 (10): 1069-1080. http://www.biodiversity-

science.net/CN/10.17520/biods.2019059

附录8 次生林与老龄林间 3 种功能性状地上部分生物量所占比例的比较 $(\%)$

Appendix 8 Comparisons of proportion of total aboveground biomass between secondary and old-growth evergreen broad-leaved forests $(\%)$

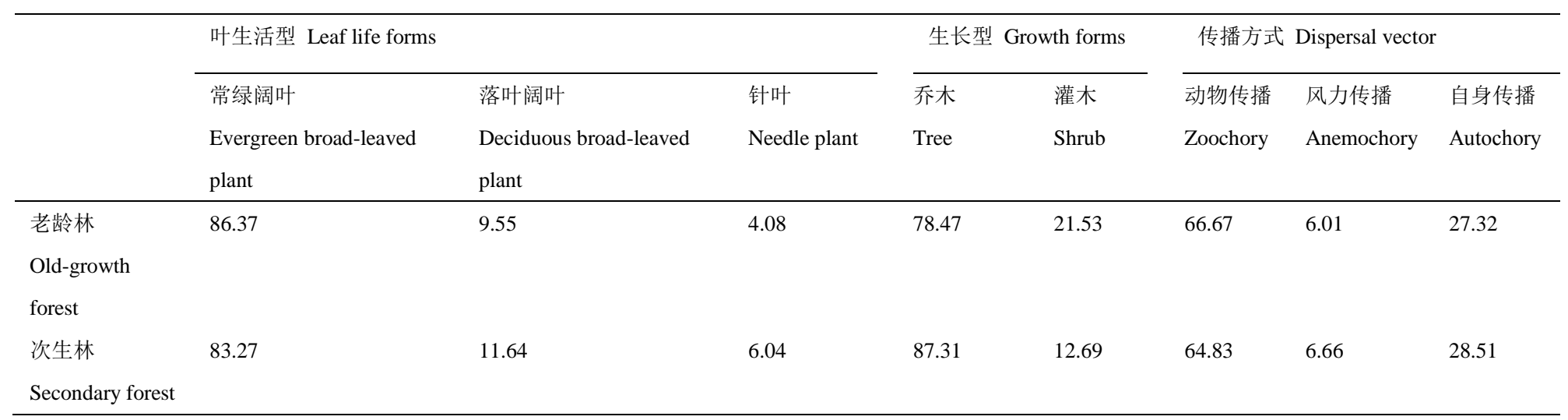

